\title{
The role of barrier membranes for guided bone regeneration and restoration of large bone defects: current experimental and clinical evidence
}

\author{
Rozalia Dimitriou ${ }^{1 \dagger}$, George I Mataliotakis ${ }^{1 \dagger}$, Giorgio Maria Calori ${ }^{2 \dagger}$ and Peter V Giannoudis ${ }^{1,3^{* \dagger}}$
}

\begin{abstract}
Treatment of large bone defects represents a great challenge in orthopedic and craniomaxillofacial surgery. Although there are several methods for bone reconstruction, they all have specific indications and limitations. The concept of using barrier membranes for restoration of bone defects has been developed in an effort to simplify their treatment by offering a sinlge-staged procedure. Research on this field of bone regeneration is ongoing, with evidence being mainly attained from preclinical studies. The purpose of this review is to summarize the current experimental and clinical evidence on the use of barrier membranes for restoration of bone defects in maxillofacial and orthopedic surgery. Although there are a few promising preliminary human studies, before clinical applications can be recommended, future research should aim to establish the 'ideal' barrier membrane and delineate the need for additional bone grafting materials aiming to 'mimic' or even accelerate the normal process of bone formation. Reproducible results and long-term observations with barrier membranes in animal studies, and particularly in large animal models, are required as well as well-designed clinical studies to evaluate their safety, efficacy and cost-effectiveness.
\end{abstract}

Keywords: bone regeneration, bone defect, barrier membranes, non-resorbable membranes, bioresorbable/absorbable membranes

\footnotetext{
* Correspondence: pgiannoudi@aol.com

+ Contributed equally

'Department of Trauma and Orthopaedics, Academic Unit, Clarendon Wing, Leeds Teaching Hospitals NHS Trust, Great George Street, Leeds LS1 3EX, UK Full list of author information is available at the end of the article
}

\section{Introduction}

Treatment of large bone defects represents a great challenge, as bone regeneration is required in large quantity and may be beyond the potential for self-healing. Large bone defects include segmental or large cortical defects created by trauma, infection, tumor resection, aseptic loosening around implants and skeletal abnormalities $[1,2]$. Critical size defect (CSD) is defined as the defect with the minimum length that cannot be spontaneously bridged leading to non-union $[2,3]$. Such defects are generally accepted to be $\geq 1.5$ to 2 times the diameter of the long bone diaphysis, but they vary according to the host and the bone [2].

Although many methods for bone reconstruction exist, they all have specific indications and limitations. Established methods are distraction osteogenesis and bone transport, or bone grafting, including autologous bone grafts, bone marrow aspirate, allografts, bone substitutes or growth factors [4-8]. Furthermore, the concept of an induced-membrane represents another strategy for bone regeneration and particularly in cases of large bone defects secondary to trauma, infection or tumor excision. This method involves a two-stage procedure, where a 'biological' membrane is induced as a foreign body response after application of a cement spacer at the first stage, acting as a 'chamber' for the insertion of autologous bone-graft at the second stage [9-11]. It has been shown that this induced membrane possesses osteoinductive, osteogenic and angiogenic properties and several clinical studies have demonstrated satisfactory results $[9,12]$. Finally, the concept of Guided Bone Regeneration (GBR) using a bioabsorbable or non-resorbable membrane that acts as a barrier to prevent soft-tissue invasion into the defect and forms a 'chamber' to 'guide' the bone regeneration process [13-15] is also used for bone reconstruction. 
Historically, the concept of GBR has been used in experimental reconstructive surgery since the mid-1950s, for spinal fusion [16] and maxillofacial reconstruction $[17,18]$. The initial hypothesis was that different cellular components in the tissue have varying rates of migration into a wound area during healing and that a mechanical hindrance would exclude the invasion of inhibiting substances, such as fibroblasts [19]. Preliminary studies showed that the use of a non-resorbable membrane as a mechanical barrier resulted in complete healing of the bone defect in vivo [20], and collagen membranes prevented the apical migration of epithelium and supported new connective tissue attachment and tissue regeneration [21]. The regeneration process occurring within the barrier membrane involves angiogenesis and migration of osteogenic cells from the periphery towards the center to create a well-vascularized granulation tissue. Initial organization of the blood clot is followed by vascular ingrowth and woven bone deposition, subsequent lamellar bone formation and finally remodeling, resembling bone growth $[22,23]$. When ingrowth of bone marrow into the bone defect was hindered or delayed, regeneration of mineralized bone was also delayed [24]. However, in large defects, bone formation occurs only to the marginal stable zone with a central zone of disorganized loose connective tissue, and, therefore, additional use of bone-graft materials is required in these cases, with the graft acting as a scaffold for osteoconduction and as a source of osteogenic and osteoinductive substances for lamellar bone formation [23].

\section{Types of barrier membranes, their basic characteristics and specific considerations}

Although different non-resorbable and bioresorbable barrier membranes have been developed and their use has been extensively investigated, research is ongoing to develop the 'ideal' membrane for clinical applications. The basic characteristics of these membranes are biocompatibility, cell-occlusiveness, space-making, tissue integration, and clinical manageability $[15,25]$.

Non-resorbable membranes and especially expandedpolytetrafuoroethylene (e-PTFE, Teflon) have been extensively studied [26]. They are biocompatible and maintain their structural integrity during implantation. They have superior space-maintaining properties and capacity for cell occlusion than degradable membranes, as the latter tend to collapse depending on the size of the defect [27]. Other non-resorbable membranes are titanium reinforced ePTFE, high-density-PTFE, or titanium mesh mainly used in oral and maxillofacial surgery [23] (Table 1). Semipermeable ePTFE is more effective than the high-density ePTFE with respect to bone regeneration [28]. For bone regeneration of large segmental bone defects, the cylindrical titanium mesh cage has been used as a scaffold with satisfactory preliminary results [29]. However, a second surgical procedure is required for removal, which represents a limitation and involves a potential risk to the newly regenerated tissues [30]. Finally, membrane exposure is frequent, increasing the risk of secondary infection [31,32].

Bioresorbable membranes have been developed to avoid the need for surgical removal. Such membranes have been extensively studied, mainly in animals but also in humans in maxillofacial, regenerative periodontal, and neuro-surgery [14,33-38]. Recently, commercially available bioresorbable membranes have also been used for reconstruction of long bone defects in the clinical setting. It has been shown that they enhance bone healing, especially in cases with bone defects $>4$ to $5 \mathrm{~cm}$ or with significant associated soft-tissue loss, where autologous bone grafting alone is not recommended due to risk of resorption [39], and they also secure the grafting material [31]. There are two broad categories of bioresorbable membranes: the natural and the synthetic membranes. Natural membranes are made of collagen or chitosan, whereas synthetic products are made of aliphatic polyesters, primarily poly(L-lactide) (PLLA) and poly(L-lactide-co-glycolide) (PLGA) co-polymers [23]. Overall, their advantages are: 1 ) they allow for a single-step procedure, 2) the shape and volume of the regenerated bone can be predefined-prefabricated, 3) they are radiolucent allowing imaging, and 4) their bioresorption eliminates potential effects of stress shielding of the regenerated bone. Conversely, there is variability and lack of control over the rate of membrane resorption, which is influenced by factors such as the local $\mathrm{pH}$ and material composition. A summary of the main characteristics, advantages and disadvantages of the different bioresorbable membranes is presented in Table $1[13,21,31$, 38,40-59]. Currently, mainly PLLA membranes are available for clinical use in orthopedic surgery; whereas PLLA, collagen and ePTFE membranes are used for GBR in maxillofacial, dental and neuro- surgery.

Although a number of barrier membranes are already being used in clinical practice, novel membranes have been developed in an effort to overcome the limitations of the currently used membranes. Such novel membranes include alginate membranes, new degradable copolymers, hybrid or nanofibrous membranes, as well as amniotic membranes. They are summarized in Table 1 [60-75]. Ongoing research is evaluating these novel membranes, aiming to establish an 'ideal' membrane for bone regeneration with optimized characteristics in terms of biocompatibility, space-making, tissue integration and clinical manageability for maximum clinical efficacy and safety. 
Table 1 Summary of the different types of barrier-membranes used for reconstruction of bone defects

\section{Types of membranes}

\begin{tabular}{|c|c|c|c|}
\hline \multicolumn{2}{|c|}{ Bioresorbable membranes } & \multirow[b]{2}{*}{$\begin{array}{l}\text { Advantages } \\
\text { - highly biocompatible (no adverse effect to surrounding } \\
\text { tissues during degradation) } \\
\text { - it promotes wound healing [41] } \\
\text { - it allows good integration with connective tissue (fibrous } \\
\text { encapsulation with differentiation of a periosteum-like tissue } \\
\text { upon the external bony surface) [42,43] } \\
\text { - osteoblasts and fibroblasts can attach to collagen } \\
\text { membranes irrespective of its origin [44] } \\
\text { - differently cross-linked collagen membranes can promote } \\
\text { cell attachment and proliferation [45] }\end{array}$} & \multirow[b]{2}{*}{$\begin{array}{l}\text { Disadvantages } \\
\text { - degradation in vivo is too rapid to maintain the structural integrity } \\
\text { necessary for bone regeneration [44] } \\
\text { - different cross-linking techniques used to prolong degradation } \\
\text { time (it varies from four weeks up to six months) }[40,41,46] \\
\text { - differently cross-linked collagen membranes can also inhibit cell } \\
\text { attachment and proliferation [45] } \\
\text { - chemicals used for cross-linking have cytotoxic effects on the } \\
\text { surrounding tissues leading to gap formation between the } \\
\text { membrane and the connective tissue and facilitate microbial } \\
\text { accumulation [43] (to address this, a non-chemical cross-linking } \\
\text { nanofibrous collagen membrane has been developed) [47] } \\
\text { - variable mechanical properties among the different available } \\
\text { membranes } \\
\text { - risk of peri-operative rupture } \\
\text { - moistening of the membrane (unavoidable in vivo) alters } \\
\text { considerably the mechanical properties [48] } \\
\text { - possible disease transmission from animals to humans [21,31] }\end{array}$} \\
\hline $\begin{array}{l}\text { Natural } \\
\text { membranes }\end{array}$ & $\begin{array}{l}\text { Collagen } \\
\text { (different subtypes, predominantly type-I collagen, } \\
\text { derived from different animals, (bovine or porcine) } \\
\text { and from different sites (tendon or dermis) [40] }\end{array}$ & & \\
\hline & Chitosan or chitosan-collagen hybrid & $\begin{array}{l}\text { - non-toxic natural polymer (polysaccharide) } \\
\text { - it enhances wound healing and bone formation [49] } \\
\text { - it has hemostatic properties [50] } \\
\text { - excellent biocompatibility [51], osteogenic cells can } \\
\text { proliferate and express osteogenic markers [51] } \\
\text { - chitosan-hybrid membranes have superior mechanical } \\
\text { properties [52,53] }\end{array}$ & - limited evidence from in vivo studies \\
\hline $\begin{array}{l}\text { Synthetic } \\
\text { membranes }\end{array}$ & $\begin{array}{l}\text { Aliphatic polyesters: PLLA, PLGA, polydioxanone } \\
\text { and their co-polymers [52-54] }\end{array}$ & $\begin{array}{l}\text { - the most commonly used and studied bioabsorbable } \\
\text { polymer } \\
\text { - commercially available and approved for clinical use } \\
\text { - by changing the composition and the manufacturing } \\
\text { procedure, resorption time, handling properties and } \\
\text { mechanical durability can be adjusted to suit the clinical } \\
\text { situation [54] } \\
\text { - different chemical compositions did not affect on bone } \\
\text { regeneration in vivo [55] } \\
\text { - slow-degrading membranes induce greater amounts of } \\
\text { neovascularization and a thinner fibrous capsule versus fast } \\
\text { degrading membranes [56] }\end{array}$ & $\begin{array}{l}\text { - they can induce host-tissue response and foreign body reactions } \\
\text { during degradation (by non-enzymatic hydrolysis) [13,38,42,57-59] } \\
\text { - the moderate cytotoxic reactions may reduce cellular adhesion } \\
\text { [43] }\end{array}$ \\
\hline \multicolumn{4}{|c|}{ Non-resorbable membranes } \\
\hline \multicolumn{2}{|c|}{$\begin{array}{l}\text { Expanded polytetrafuoroethylene (e-PTFE) } \\
\text { And others: titanium reinforced ePTFE, high-density-PTFE, or } \\
\text { titanium mesh [23] }\end{array}$} & $\begin{array}{l}\text { - extensively studied [26] } \\
\text { - biocompatible } \\
\text { - they maintain their structural integrity during implantation } \\
\text { and have superior space-maintaining properties and capacity } \\
\text { for cell occlusion than degradable membranes } \\
\text { - semipermeable ePTFE is more effective than the high- } \\
\text { density ePTFE [28] } \\
\text { - for large segmental bone defects, cylindrical titanium mesh } \\
\text { cage used as a scaffold [29] }\end{array}$ & $\begin{array}{l}\text { - a second surgical procedure is required for removal (additional } \\
\text { potential risk to the newly regenerated tissues [30]) } \\
\text { - membrane exposure is frequent, increasing the risk of secondary } \\
\text { infection [31,32] } \\
\text { - e-PTFE can induce slight to moderate cytotoxic reactions and } \\
\text { reduce cellular adhesion }\end{array}$ \\
\hline
\end{tabular}


Table 1 Summary of the different types of barrier-membranes used for reconstruction of bone defects (Continued)

\begin{tabular}{ll}
\hline Novel membranes & \\
\hline Alginate membrane & - close assimilation to bone surface \\
& - no inflammatory response [60] \\
& - easy handling with an alginate base self-setting barrier \\
& membrane versus a ready-made membrane [61] \\
& - more efficacious versus collagen membranes for mandibular \\
& and tibial defects [62,63]
\end{tabular}




\section{The role of porosity and topography of the barrier membranes}

The pore size of the barrier membrane is very important in order to prevent excessive penetration of fibrous tissue into the bone defect (soft tissue ingrowth) but to allow neovascularization and bone formation. Differences in the intensity of bone regeneration were observed depending on the pore size [76]. Pores in excess of $100 \mu \mathrm{m}$ are required for the rapid penetration of highly vascular connective tissue, and small pores tend to become filled with more avascular tissue [77], as they are inadequate for penetration of capillaries [78]. A pore size of 50 to $100 \mu \mathrm{m}$ allows bone ingrowth, but size greater than $150 \mu \mathrm{m}$ is required for osteon formation $[79,80]$. A recent animal study showed that macroporous membranes facilitated greater bone regeneration compared to microporous membranes and prevented significant soft-tissue ingrowth [81]. Further research should be directed to identify the critical pore size, since an increase in pore size may result in decreased mechanical properties. A multilayer scaffold has been suggested to achieve suitable mechanical properties and porosity and mimic the structure of cancellous and cortical bone [82]. In addition to the porosity, the tridimensional topography of the membrane with interconnecting pores and channels is also important, as it can alter the cell occlusion properties and the biologic response of different cell types to the membrane [83].

\section{The role of soft tissue ingrowth}

Although barrier membranes are used to prevent soft-tissue invasion, a thin layer of soft-tissue ingrowth (up to 1 $\mathrm{mm}$ thickness) can be formed under the membrane, overlying the regenerated bone [84-86]. This may be secondary to shrinkage of the initial blood clot under the membrane, entrapment of air or membrane micromovements. Currently, it is not known if this soft-tissue layer under the membrane undergoes mineralization if left for a long period. Some studies reported this tissue-layer was a periosteum-like tissue, and others reported it to be fibrous tissue [81] but its clinical implications are unknown.

\section{The role of mechanical stability}

It is known that micromovements between bone and any implanted material prevent bone formation, resulting in the development of fibrous tissue $[87,88]$. Adequate stability and minimal stress are required to allow the early tissue that infiltrates through the pores to differentiate into bone by direct or appositional bone formation [81]. Bone formation can occur within porous materials even with limited initial movement provided the site is highly vascular and local inflammatory reaction is minimal [89]. New vascular network formation, which is a prerequisite for bone formation, is also highly sensitive to mechanical conditions with delayed mechanical loading significantly enhancing bone formation and stimulating vascular remodelling by increasing the number of large vessels and decreasing the number of small vessels [90]. Therefore, optimal stability should be provided in terms of the attachment of the membrane itself, since most bioresorbable membranes are flexible and they cannot be applied without additional fixation as well as the type of fixation of the bone defect [91]. To maximize stability of the membrane, the use of membrane-fixing pins has been suggested. It has been observed that bone formation is significantly enhanced when the resorbable membrane is tightly attached and immobilized to the bone surface [92]. Regarding the effect of the type of additional fixation to the process of bone formation, it is known that intermediate tissues, such as fibrous tissue, cartilage and woven bone, precede final bone formation, with the mechanical loading affecting the regeneration process and different stress distribution favoring or inhibiting differentiation of particular tissue phenotypes [93]. High shear strain and fluid flows stimulate fibrous tissue formation, whereas lower levels stimulate formation of cartilage, and even lower levels favor ossification. It has been demonstrated in vivo that there is more rapid and more organized new bone formation in rigidly fixed defects with plate osteosynthesis, covered with a resorbable collagen membrane, compared to non-rigidly fixed defects [94].

\section{Literature Review}

As research on the field of bone regeneration is ongoing and the evidence is expanding, we aimed to summarize the current experimental and clinical research on the use of barrier membranes for restoration of bone defects and focus on maxillofacial and orthopedic applications. We searched the PubMed Medline and Ovid Medline databases, from 1991 to 2011, to retrieve all relevant articles reporting on the use of absorbable and/or nonabsorbable membranes for bone regeneration in animal and clinical studies. Different combinations of searching terms were used including: membrane/bone regeneration/long bone/bone defect/segmental bone defect/segmental mandibular defect/mandibular defect. The search was restricted to studies published in English. We analyzed all preclinical studies using established animal models to evaluate barrier membranes for bone regeneration of segmental, large and critical-sized mandibular or long-bone defects, in which bone regeneration was documented and assessed using radiological or biomechanical and/or histological analysis. Regarding the clinical studies, all papers reporting on the clinical use of barrier membranes were analyzed. 
The majority of studies were preclinical and the clinical studies were mainly retrospective case series. The summaries of the studies are shown in Tables 2 to 7 .

\section{Animal studies}

Tables 2 to 5 summarize the preclinical studies with nonabsorbable or bioabsorbable membranes. There were 23 animal studies reporting on the use of membranes in maxillo-facial surgery for reconstruction of segmental or critical mandibular defects using small or large animal models (Table 2, 15 studies [31,34,54,63,64,94-103] and Table 3, 8 studies [22,104-110], respectively). Overall, the membrane-treated groups showed improved bone formation within the mandibular defects compared to the nontreated animals $[22,96,98]$. Differences in the rate of bone regeneration and the inflammatory response in the surrounding soft tissues were observed with different types of membranes [31,97,100].

A total of 27 animal studies reported on the use of membranes for reconstruction of long bone defects. There were 21 studies using a small animal model (Table 4) [55,60,62,76,82,111-126], and only six studies using a large animal model (Table 5) [127-132]. As in maxillofacial animal studies, superior bone healing has also been observed in long bones treated with a barrier-membrane compared to the non-treated defects using bioabsorbable as well as non-resorbable membranes [111,117,118,121]. Bone defects treated with improved bilayer membranes displayed better regeneration of cortical bone tissue [112], whereas novel composite membranes displayed affluent neovascularization and bone formation with little fibrous tissue formation [82]. The differences in chemical composition of the polylactide membranes did not seem to have an evident effect on bone healing in a small animal model [55], but different pore sizes resulted in differences in the intensity of the bone regeneration process [76]. Large animal studies also showed promising results for restoration of long bone defects but only when combined with additional bone grafting material $[131,132]$. When two concentric perforated membranes (the tube-in-tube implant) were used in combination with cancellous bone graft in segmental diaphyseal defects, a 'neocortex' was reconstituted with well-defined thickness [132].

\section{Clinical studies}

Tables 6 and 7 summarize the clinical studies, in which absorbable membranes were used for bone regeneration of the mandible and the long bones, respectively. The absorbable membranes used were either experimental materials $[57,133]$, similar to the ones used in the animal studies, or commercially available material manufactured for other purposes $[13,134]$.

There are only three studies in humans where bioabsorbable membranes have been used for reconstruction of segmental or large mandibular bone defects using bioresorbable PLLA barrier membrane (mesh) in combination with autologous bone graft (Table 6) [33,57,133]. The majority of the bone defects were secondary to benign or malignant tumors of the mandible, but other causes included infection, alveolar atrophy and trauma. Overall, the preliminary clinical results were satisfactory (rated as excellent and good in 56.5\% and $27.4 \%$, respectively). Radiologically, a certain degree of bone absorption was noted in more than half of the cases; nevertheless, only in one case was the absorption significant (up to $30 \%$ ).

Finally, regarding the use of bioabsorbable membranes in long bone defects, there are only two clinical studies reporting on the clinical results in a total of 16 patients (Table 7) [13,134]. Long bone defects were mainly posttraumatic, but there were also a few cases of osteomyelitis and benign tumor resection. The bioresorbable PLLA synthetic membrane used was used in combination with autologous cancellous bone graft or bone marrow, and long bone fixation. Preliminary results showed healing of the defects and satisfactory function in all cases, except one which required further intervention.

\section{Discussion}

Barrier membranes are among the most widely studied scaffolds for tissue regeneration, including bone, and the choice of type of membrane depends largely on the required duration of membrane function [23]. Regarding bone regeneration, their use is mainly indicated for bone regeneration in sites where limited mechanical loading exists, such as in cranial, oral and maxillofacial applications. Even though there is extensive research on barrier membranes in animals, human studies are still few. Therefore, the most reliable current evidence originates mainly from studies in animals of higher phylogenetic scale which are still limited in number. Findings from the experimental setting indicate that GBR follows the same course of steps regardless of the animal. Bone quality though is highly dependent on the species (evolution hierarchy), bone healing potential (age, general nutritional status), the membrane used, local conditions (vascularity, embryological origin of bone) and load-sharing pattern of the fixation method; and, therefore, the results and the potential clinical use should be interpreted with caution $[2,13,33,76,123,130]$.

\section{Long bone versus maxillofacial bone defects}

According to the preliminary clinical reports, the time period for complete regeneration of bone in the mandible is three months, whereas long bones require more than two times the same period (seven months) [33,57]. This is most likely to be attributed to the greater vascularity of the mandible and the surrounding soft tissues as well as 
\begin{tabular}{llll} 
Table 2 & Summary of studies using membranes for segmental mandibular defects in small animal models \\
\hline Author/ & Animal & Type of membrane & Study design
\end{tabular}

Assessment of bone regeneration Outcome

Kazakos Rabbits platelet-rich plasma (PRP) gel alone or Group I: HFL

$2011 \quad$ mandible human fascia lata membrane (HFL) Group II: PRP gel

Histological at 12 weeks

None of the control sides and the PRP

treated sides had full development of bone

or filling of the defect through bone

bridging.

The application of PRP gel alone or in

combination with HFL does not seem to

enhance bone regeneration.

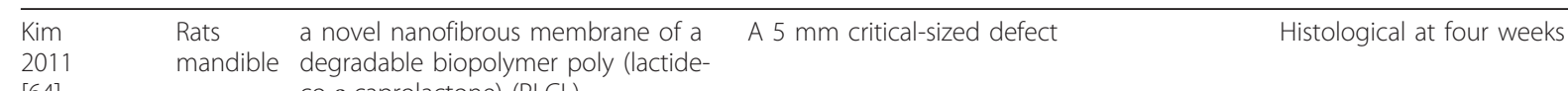

The assessment of cell compatibility showed favorable cell adhesion and growth on the nanofiber PLCL membrane. At four weeks, the PLCL nanofibrous membrane induced better guided new bone formation than the defect control group while protecting the bone defect against the ingrowth of fibrous tissues.

For defect closure and bone thickness all

membrane-treated groups showed effect modification between time and membrane; polytetrafluoroethylene (ePTFE) uncovered (control). modification between time and membrane; these effects were more significant and larg in the collagen and EPTFE groups. In the non-treated controls no effect modification was observed. The membrane groups showed significantly better results than the control groups. The ePTFE and collagen membranes performed equally well and better than the PDLLCL membrane during this experiment. PDLLCL membrane not suitable for clinical application in its current form.

\begin{tabular}{|c|c|c|c|c|c|}
\hline $\begin{array}{l}\text { Gielkens } \\
\text { 2008 } \\
\text { [31] }\end{array}$ & $\begin{array}{l}\text { Rats } \\
\text { Mandible }\end{array}$ & $\begin{array}{l}\text { a novel degradable synthetic } \\
\text { membrane (Vivosorb) of poly(dl- } \\
\text { lactide-epsilon-caprolactone) (PDLLCL) } \\
\text { versus collagen and ePTFE } \\
\text { membranes }\end{array}$ & $\begin{array}{l}\text { A standardized } 5 \mathrm{~mm} \text { circular mandibular } \\
\text { defect } \\
\text { Four groups (control/uncovered, PDLLCL, } \\
\text { collagen, ePTFE). }\end{array}$ & $\begin{array}{l}\text { At 2, 4, and } 12 \text { weeks } \\
\text { Microradiography and muCT }\end{array}$ & $\begin{array}{l}\text { Bone formation was progressive when the } \\
\text { defect was covered with a membrane. More } \\
\text { bone formation was observed underneath } \\
\text { the collagen and ePTFE membranes than the } \\
\text { PDLLCL membranes. } \\
\text { Bone formation in PDLLCL-covered defects } \\
\text { was less and the high variation in the PDLLCL } \\
\text { samples at } 12 \text { weeks may be caused by the } \\
\text { moderate adherence of this membrane to } \\
\text { bone compared with collagen. }\end{array}$ \\
\hline $\begin{array}{l}\mathrm{He} \\
2008 \\
{[97]}\end{array}$ & $\begin{array}{l}\text { Rabbits } \\
\text { mandible }\end{array}$ & $\begin{array}{l}\text { a novel calcium alginate film (CAF) } \\
\text { versus conventional collagen } \\
\text { membrane (CM) }\end{array}$ & $\begin{array}{l}\text { Bilateral critical size } 5 \mathrm{~mm} \text { mandibular defects } \\
\text { covered with CAF (experimental group) or } \\
\text { conventional collagen membrane (CM) or left } \\
\text { empty (control group) }\end{array}$ & $\begin{array}{l}\text { At one, two, four, six and eight } \\
\text { weeks. Morphological and } \\
\text { histomorphometric evaluation }\end{array}$ & $\begin{array}{l}\text { The CAF guided early bone growth and } \\
\text { appeared more effective as a bioabsorbable } \\
\text { GTR membrane than CM. } \\
\text { A significantly greater percentage of newly } \\
\text { generated bone in CAF defects than that in } \\
\text { CM defects and empty defects from two to } \\
\text { six weeks post-operation. } \\
\text { At six and eight weeks, significantly more } \\
\text { mature lamella bone had formed with CAF } \\
\text { than with CM. }\end{array}$ \\
\hline
\end{tabular}




\begin{tabular}{|c|c|c|c|c|c|}
\hline $\begin{array}{l}\text { Thomaidis } \\
\text { 2008 } \\
\text { [34] }\end{array}$ & $\begin{array}{l}\text { Rabbit } \\
\text { mandible }\end{array}$ & $\begin{array}{l}\text { five different membranes: } \\
\text { - HFL (human fascia lata) } \\
\text { - HP (human pericardium) } \\
\text { - HFT (human fascia temporalis) } \\
\text { - BP (bovine pericardium), } \\
\text { - e- PTFE }\end{array}$ & $\begin{array}{l}\text { 9-mm circular mandibular defects were } \\
\text { created bilaterally. } \\
\text { Five groups for each membrane and the } \\
\text { defect on the other side served as a control. }\end{array}$ & Histological at ten weeks & $\begin{array}{l}\text { Membranes were significantly superior to the } \\
\text { controls. } \\
\text { HFL, HP, BP, and PTFE were significantly } \\
\text { superior to HFT } \\
\text { HFT is not recommended for GBR techniques } \\
\text { for osseous defects beyond the critical size. }\end{array}$ \\
\hline $\begin{array}{l}\text { Asikainen } \\
2006 \\
{[54]}\end{array}$ & $\begin{array}{l}\text { Rabbit } \\
\text { mandible }\end{array}$ & $\begin{array}{l}\text { poly(desaminotyrosyl-tyrosine-ethyl } \\
\text { ester carbonate) (PDTE carbonate) } \\
\text { membrane (thickness } 0.2-0.3 \mathrm{~mm} \text { ) }\end{array}$ & $\begin{array}{l}\text { A through-and-through defect }(12 \times 6 \mathrm{~mm}) \text {. } \\
\text { Group 1: defects left unfilled but covered } \\
\text { with membrane } \\
\text { Group 2: defects filled with bioactive glass } \\
\text { mesh and covered with membrane } \\
\text { Controls were left uncovered and unfilled. }\end{array}$ & $\begin{array}{l}\text { Histological at 6, 12, } 24 \text { and } 52 \\
\text { weeks }\end{array}$ & $\begin{array}{l}\text { PDTE carbonate elicited a modest foreign } \\
\text { body reaction in the tissues, which was } \\
\text { uniform throughout the study. New bone } \\
\text { formation was seen in all samples after six } \\
\text { weeks. Group } 1 \text { had more new bone } \\
\text { formation until } 24 \text { weeks and after this the } \\
\text { difference settled. PDTE carbonate } \\
\text { membranes have good biocompatibility and } \\
\text { are sufficient to enhance bone growth } \\
\text { without additional supportive matrix. }\end{array}$ \\
\hline $\begin{array}{l}\text { Jianqi } \\
2002 \\
{[63]}\end{array}$ & $\begin{array}{l}\text { Rabbit } \\
\text { mandible }\end{array}$ & calcium alginate film (CAF) with CM & $\begin{array}{l}\text { Circular bone defects with } 5-\mathrm{mm} \text { diameter } \\
\text { one side were covered with a CAF, and the } \\
\text { contralateral side with CM. }\end{array}$ & $\begin{array}{l}\text { gross, radiographic, } \\
\text { electromicroscopic, histologic, and } \\
\text { immunohistochemical analyses and } \\
\text { image pattern analysis system at } \\
\text { one, two, four, six, and eight weeks }\end{array}$ & $\begin{array}{l}\text { CM absorbed more slowly but collected } \\
\text { fewer osteoinductive factors }(P<.05) \text { in the } \\
\text { early period. CAF induced dense bone } \\
\text { formation, whereas CM produced less newly } \\
\text { formed bone. } \\
\text { CAF is more efficacious than CM in guided } \\
\text { bone regeneration in this animal model. }\end{array}$ \\
\hline $\begin{array}{l}\text { Stetzer } \\
2002 \\
{[94]}\end{array}$ & $\begin{array}{l}\text { Rabbit } \\
\text { mandible }\end{array}$ & collagen membrane & $\begin{array}{l}\text { Bilateral critical size }(4 \mathrm{~mm}) \text { defects maxillary } \\
\text { segments were rigidly or not rigidly fixed } \\
\text { using bone microplates and screws or } \\
\text { osteosynthetic wires. The defects were } \\
\text { covered with a resorbable collagen } \\
\text { membrane or left uncovered. }\end{array}$ & $\begin{array}{l}\text { At four weeks } \\
\text { serial radiographs and histologic/ } \\
\text { histomorphometric analyses }\end{array}$ & $\begin{array}{l}\text { The rigidly fixed defects, covered with } \\
\text { membrane, showed the most rapid and } \\
\text { organized new bone formation. They } \\
\text { averaged approximately } 40 \% \text { more new bone } \\
\text { in the osteotomy site compared with the } \\
\text { rigidly fixed defects with no membrane. No } \\
\text { rigidly fixed defects with no membrane } \\
\text { showed an ingrowth of fibroblasts and } \\
\text { fibrous non-unions. }\end{array}$ \\
\hline $\begin{array}{l}\text { Zahedi } \\
1998 \\
{[98]}\end{array}$ & $\begin{array}{l}\text { Rats } \\
\text { mandible }\end{array}$ & $\begin{array}{l}\text { diphenylphosphorylazide-crosslinked } \\
\text { type I bovine collagen membrane } \\
\text { (DPPA) }\end{array}$ & $\begin{array}{l}5 \mathrm{~mm} \text { diameter full-thickness circular bone } \\
\text { defects } \\
\text { one side covered by the membrane } \\
\text { the other side uncovered (control) }\end{array}$ & $\begin{array}{l}\text { Histological at 7, 15, 30, 90, and } 180 \\
\text { days }\end{array}$ & $\begin{array}{l}\text { Although at early stages of healing similar } \\
\text { amounts of bone formation were observed in } \\
\text { the both groups, after one month of healing, } \\
\text { most of the experimental defects were } \\
\text { completely closed with new bone, while in } \\
\text { the control defects, only limited amounts of } \\
\text { new bone were observed at the rims and in } \\
\text { the lingual aspect of the lesions. In the } 90- \\
\text { and 180-day animals, all experimental defects } \\
\text { were completely closed, while in the control } \\
\text { defects, no statistically significant increase in } \\
\text { bone regeneration was observed. }\end{array}$ \\
\hline
\end{tabular}




$1995 \quad$ mandible $\quad$ (GORE-TEX)

[99] mandibles of rats were either implanted with histomorphological scoring system recombinant human bone morphogenetic

protein type 2 (rhBMP-2) or were left empty

half the number of implanted and half the

number of empty defects were covered with

the e-PTFE membrane

\begin{tabular}{lll}
\hline Zellin & Rats & ten different biodegradable and non- \\
1995 & mandible & biodegradable membrane materials \\
{$[100]$} & &
\end{tabular}

1995 mandible biodegradable membrane materials

Standardized bilateral critical size mandibular defects and randomly covered with the different types of membrane

Implantation of rhBMP-2 alone resulted in bony bridging of the defect after only 12 days, but also in voluminous amounts of new bone outside the original defect area. When rhBMP-2 was combined with membrane, newly formed woven bone bridged the defect and the bone contour was maintained by the membrane by the membrane. The combined treatment with membrane and hBMP-2 demonstrated a significantly better bone healing than with e-PTFE membrane alone at both 12 days and 24 days of healing. RhBMP-2 had a strong osteoinductive potential and this potential was retained when combining the rhBMP-2 with the osteopromotive membrane technique, yielding better bone healing than with the membrane alone, and at the same time maintaining the bone contour.

At six weeks, varying degrees of bone healing seen beneath the different membranes. Some of the membranes revealed a good osteopromotive effect, whereas others had little or no beneficial effects on bone healing, even if seemingly chemically closely related. Certain membrane materials caused a pronounced inflammatory response in the surrounding soft tissue, while others displayed a low inflammatory reaction.

\begin{tabular}{lll}
\hline Dahlin & Rats & e-PTFE membrane \\
1994 & mandible
\end{tabular}

Standardized through-and-through critical size defects (non-union)

On one side of the jaw, the defect was

covered both buccally and lingually with an

expanded polytetrafluoroethylene (e-PTFE)

membrane.

On the other side no membrane was used.
Complete healing with bone of the membrane-covered defects at six weeks. No cartilage was present in any of the specimens. At the control sites (no membrane), the amount of newly produced bone showed variations, most through defects revealing the presence of a remaining central portion of connective tissue.

Kostopoulos Rats a polyhydroxybutyrate resorbable

A $2 \times 3 \mathrm{~mm}$ defect mandible membrane

the contralateral side: no membrane

Histological analysis from 15 days to

The histological analysis demonstrated increasing bone fill in the test specimens from 15 to 180 days, whereas only $35 \%$ to $40 \%$ of the defect area in the control sides was filled with bone after 3 to 6 months. Ingrowth of muscular, glandular and connective tissue was consistently occurring in the control defects during healing.

Sandberg Rats three types of bioabsorbable

Standardized $5 \mathrm{~mm}$ critical size defects

Histological at 1 to 12 weeks

[103]

membranes (BAMs) of polylactic/
polyglycolic acid copolymers with

different absorption times and

comparisons with e-PTFE membrane.
BAMs were well tolerated by the tissue, causing just a mild inflammatory reaction
along the membrane surfaces as long as the material remained in the tissue. The BAMs were as efficient as e-PTFE membranes. Healing in conjunction with one type of BAM seemed to occur somewhat more rapidly.

BAMs represent a valid alternative to ePTFE membranes to improve bone regeneration. 
Table 3 Summary of studies using membranes for segmental mandibular defects in large animal models

\begin{tabular}{|c|c|c|c|c|c|}
\hline $\begin{array}{l}\text { Author/ } \\
\text { Year } \\
\text { [ref] }\end{array}$ & $\begin{array}{l}\text { Animal } \\
\text { model }\end{array}$ & Type of membrane & Study design & $\begin{array}{l}\text { Assessment of bone } \\
\text { regeneration }\end{array}$ & Outcome \\
\hline $\begin{array}{l}\text { Jégoux } \\
2010 \\
{[104]}\end{array}$ & $\begin{array}{l}\text { Dogs } \\
\text { Mandible }\end{array}$ & collagen & $\begin{array}{l}\text { Segmental defects after mandibulectomy using } \\
\text { calcium phosphate ceramics and collagen } \\
\text { membrane with a delayed bone marrow grafting } \\
\text { (after two months, bone marrow injection) }\end{array}$ & $\begin{array}{c}\text { At 16-weeks } \\
\text { Histological and scanning } \\
\text { electronic microscopic analysis } \\
\text { and X-ray microtomographic } \\
\text { analysis }\end{array}$ & $\begin{array}{l}\text { Successful osseous colonization bridged the entire } \\
\text { length of the defects. The good new bone } \\
\text { formation at the center and the periosteum-like } \\
\text { formation at the periphery suggest the } \\
\text { osteoinductive role of the bone marrow graft and } \\
\text { the healing scaffold role of the membrane. }\end{array}$ \\
\hline $\begin{array}{l}\text { Borges } \\
2009 \\
{[105]}\end{array}$ & $\begin{array}{l}\text { Dogs } \\
\text { mandible }\end{array}$ & $\begin{array}{l}\text { acellular dermal matrix (ADM) in } \\
\text { comparison with a bioabsorbable } \\
\text { synthetic membrane }\end{array}$ & $\begin{array}{l}\text { Control group (bioabsorbable membrane made } \\
\text { of glycolide and lactide copolymer) } \\
\text { Test group (ADM as a membrane). }\end{array}$ & $\begin{array}{l}\text { At } 8 \text { and } 16 \text { weeks, } \\
\text { radiological evaluation } \\
\text { At } 16 \text { weeks: Clinical } \\
\text { measurements of the width } \\
\text { and thickness of the } \\
\text { keratinized tissue and } \\
\text { histomorphometric analysis }\end{array}$ & $\begin{array}{c}\text { ADM acted as a barrier in GBR, with clinical, } \\
\text { radiographic and histomorphometric results similar } \\
\text { to those obtained with the bioabsorbable } \\
\text { membrane }\end{array}$ \\
\hline $\begin{array}{l}\text { Sverzut } \\
2008 \\
{[106]}\end{array}$ & $\begin{array}{c}\text { Dogs } \\
\text { mandible }\end{array}$ & $\begin{array}{l}\text { poly L/DL-lactide } 80 / 20 \% \text { membrane } \\
\text { with different permeability patterns }\end{array}$ & $\begin{array}{l}10 \mathrm{~mm} \text { segmental defects } \\
\text { Mechanical stabilization and } 6 \text { treatment groups: } \\
\text { control, BG alone (bone graft), microporous } \\
\text { membrane (poly L/DL-lactide 80/20\%) (Mi); Mi } \\
\text { plus BG; microporous laser-perforated ( } 15 \mathrm{~cm} 2 \\
\text { ratio) membrane (Mip), and Mip plus BG. }\end{array}$ & $\begin{array}{c}\text { Histological, } \\
\text { histomorphometry and } \\
\text { fluorescence microscopy at six } \\
\text { months }\end{array}$ & $\begin{array}{l}\text { BG protected by Mip was consistently related to } \\
\text { larger amounts of bone versus other groups. No } \\
\text { difference between defects treated with Mip alone } \\
\text { and BG alone. Mi alone rendered the least bone } \\
\text { area and reduced the amount of grafted bone to } \\
\text { control levels. Bone formation was incipient in the } \\
\text { BG group at three months regardless of whether } \\
\text { or not it was covered by membrane. In contrast, } \\
\text { GBR with Mip tended to enhance bone formation } \\
\text { activity at three months. } \\
\text { The use of Mip alone could be a useful alternative } \\
\text { to BG. The combination of Mip membrane and BG } \\
\text { efficiently delivered increased bone amounts in } \\
\text { segmental defects compared with other treatment } \\
\text { modalities. }\end{array}$ \\
\hline $\begin{array}{l}\text { Bornstein } \\
2007 \\
{[107]}\end{array}$ & $\begin{array}{l}\text { Dogs } \\
\text { mandibles }\end{array}$ & $\begin{array}{l}\text { two bioabsorbable collagen } \\
\text { membranes: } \\
\text { collagen membrane versus cross- } \\
\text { linked collagen membrane (CCM). }\end{array}$ & $\begin{array}{l}\text { three standardized defects filled with bone chips } \\
\text { and deproteinized bovine bone mineral (DBBM), } \\
\text { and covered by three different methods: control } \\
=\text { no membrane; test } 1=\text { collagen membrane; } \\
\text { and test } 2 \text { = cross-linked collagen membrane } \\
\text { (CCM). Each side of the mandible was allocated } \\
\text { to one of two healing periods ( } 8 \text { or } 16 \text { weeks). }\end{array}$ & $\begin{array}{c}\text { At } 8 \text { and } 16 \text { weeks } \\
\text { Histomorphometric analysis }\end{array}$ & $\begin{array}{l}\text { For all groups, the defect fill height increased } \\
\text { between weeks } 8 \text { and } 16 \text {. The CCM group showed } \\
\text { a statistically significant increase over time and the } \\
\text { highest value of all treatment modalities after } 16 \\
\text { weeks of healing. The CCM showed a limited } \\
\text { beneficial effect on bone regeneration in } \\
\text { membrane-protected defects in dog mandibles } \\
\text { when healing was uneventful. However, the } \\
\text { increased complication rate with CCM requires a } \\
\text { more detailed preclinical and clinical examination. }\end{array}$ \\
\hline $\begin{array}{l}\text { Zubery } \\
2007 \\
{[108]}\end{array}$ & $\begin{array}{c}\text { Dogs } \\
\text { mandibles }\end{array}$ & $\begin{array}{c}\text { type I collagen membrane (GLYM) } \\
\text { using a novel cross-linking } \\
\text { technology versus a non-cross-linked } \\
\text { bilayer type I and III collagen } \\
\text { membrane (BCM) }\end{array}$ & $\begin{array}{c}\text { Mandibular bilateral critical size defects } \\
\text { five groups: GLYM + bovine bone mineral (BBM), } \\
\text { BCM + BBM, BBM alone, sham-operated, or GLYM } \\
\text { alone. }\end{array}$ & $\begin{array}{l}\text { At } 8,16 \text {, and } 24 \text { weeks, } \\
\text { Qualitative, semiquantitative, } \\
\text { and quantitative light } \\
\text { microscopy analyses }\end{array}$ & $\begin{array}{l}\text { Membrane-protected sites displayed bone filling } \\
\text { between the BBM particles with almost complete } \\
\text { restoration of the original ridge morphology that } \\
\text { increased with time up to } 16 \text { weeks and remained } \\
\text { unchanged at } 24 \text { weeks. Both membranes showed } \\
\text { marked degradation within } 16 \text { to } 24 \text { weeks, with } \\
\text { BCM inconsistency that was undetectable in one } \\
\text { of four sites at } 8,16 \text {, and } 24 \text { weeks. Membrane } \\
\text { ossification was observed in all GLYM sites and in } \\
\text { only one BCM site, which progressed with time to } \\
24 \text { weeks. Bone increased by approximately } 1 \text { mm } \\
\text { on the lingual side, where the GLYM membrane } \\
\text { was in direct contact with bone. }\end{array}$ \\
\hline
\end{tabular}


Table 3 Summary of studies using membranes for segmental mandibular defects in large animal models (Continued)

\begin{tabular}{|c|c|c|c|c|c|}
\hline $\begin{array}{l}\text { Peled } \\
2002 \\
{[109]}\end{array}$ & $\begin{array}{l}\text { Dogs } \\
\text { mandibles }\end{array}$ & $\begin{array}{c}\text { titanium-reinforced expanded ePTFE } \\
\text { membrane (ePTFE-TR) }\end{array}$ & $\begin{array}{l}\text { Mandibulectomy defects }(25 \mathrm{~mm} \times 15 \mathrm{~mm} \text { ) } \\
\text { ePTFE-TR or control (repositioning flaps) }\end{array}$ & $\begin{array}{l}\text { At four to six months } \\
\text { Macroscopic and histological/ } \\
\text { histomorphometric evaluation }\end{array}$ & $\begin{array}{c}\text { The size of the residual defect in the experimental } \\
\text { sites was much smaller compared to the controls, } \\
\text { which was statistically significant. } \\
\text { Histomorphometric measurements of new bone } \\
\text { formation revealed a similar pattern. These } \\
\text { differences were also statistically significant. }\end{array}$ \\
\hline $\begin{array}{l}\text { Fritz } \\
2000 \\
{[110]}\end{array}$ & $\begin{array}{l}\text { Macaca } \\
\text { mulatta } \\
\text { monkeys } \\
\text { Mandibles }\end{array}$ & reinforced ePTFE membranes & $\begin{array}{l}\text { Standardized } 8 \times 19 \mathrm{~mm} \text { mandibular defects } \\
\text { Reinforced ePTFE membranes held in place with } \\
\text { mini screws and sutures for anywhere from } 1 \text { to } \\
12 \text { months. No material added to the defect. }\end{array}$ & $\begin{array}{c}\text { Digital subtraction radiology } \\
\text { and fluorescent labelling with } \\
\text { tetracycline and } \\
\text { histomorphometry }\end{array}$ & $\begin{array}{l}\text { Data suggest that membranes left in situ for } 1 \\
\text { month or less result in minimal bone gain } \\
\text { compared with membranes left in place from } 2 \text { to } \\
12 \text { months. In addition, labelling and stained } \\
\text { sections clearly showed that the bone produced } \\
\text { after } 2 \text { months of membrane placement is mature. }\end{array}$ \\
\hline $\begin{array}{c}\text { Schenk } \\
1994 \\
{[22]}\end{array}$ & $\begin{array}{l}\text { Dogs } \\
\text { mandibles }\end{array}$ & $\begin{array}{c}\text { standard and prototype reinforced e- } \\
\text { PTFE membranes }\end{array}$ & $\begin{array}{l}\text { Standard and prototype reinforced e-PTFE } \\
\text { membranes and control (no membranes) }\end{array}$ & $\begin{array}{l}\text { At two and four months } \\
\text { Histologic evaluation }\end{array}$ & $\begin{array}{l}\text { Control sites without membranes exhibited } \\
\text { incomplete osseous healing with a persisting } \\
\text { defect. Test sites with membranes demonstrated } \\
\text { significantly better bone healing, although bone } \\
\text { regeneration was not yet completed at } 4 \text { months. } \\
\text { Histologic evaluation showed that bone } \\
\text { regeneration, once activated, progresses in a } \\
\text { programmed sequence which closely resembles } \\
\text { the pattern of bone development and growth. }\end{array}$ \\
\hline
\end{tabular}


Table 4 Summary of studies using resorbable membranes for long bone defects in small animal models

\begin{tabular}{|c|c|c|c|c|c|}
\hline $\begin{array}{l}\text { Author/ } \\
\text { Year [ref] }\end{array}$ & $\begin{array}{c}\text { Animal } \\
\text { model }\end{array}$ & Type of membrane & Study design & $\begin{array}{l}\text { Assessment of bone } \\
\text { regeneration }\end{array}$ & Outcome \\
\hline $\begin{array}{l}\text { Bernabé } \\
2012 \\
{[111]}\end{array}$ & Rats tibia & $\begin{array}{l}\text { decalcified cortical } \\
\text { osseous membrane } \\
{\left[\text { GenDerm }\left({ }^{\circledR}\right)\right]}\end{array}$ & $\begin{array}{c}\text { To study the effect of using lyophilized bovine bone } \\
\left(\text { GenOx }\left({ }^{\circledR}\right) \text { organic matrix) with (or without) GBR }\right. \\
\text { (using a decalcified cortical osseous membrane } \\
\left.\text { [GenDerm }\left({ }^{\mathbb{B}}\right)\right] \text { ) } \\
\text { Surgically created critical-size defects } \\
\text { group I (control) } \\
\text { group II (defect filled with GenOx }\left({ }^{\circledR}\right) \\
\text { group III (defect covered by GenDerm }\left({ }^{\circledR}\right) \\
\text { group IV (defect filled with GenOx }\left({ }^{\mathbb{B}}\right) \text { and covered } \\
\text { by GenDerm }\left({ }^{(}\right)\end{array}$ & $\begin{array}{l}\text { At } 30 \text { or } 90 \text { days } \\
\text { Histological and } \\
\text { histomorphometrical }\end{array}$ & $\begin{array}{c}\text { Superior bone healing in all groups compared to } \\
\text { control group. } \\
\text { Group IV showed evidence of more advanced } \\
\text { healing at } 30 \text { and } 90 \text { days compared with the other } \\
\text { groups. }\end{array}$ \\
\hline $\begin{array}{l}\text { Cai } \\
2010 \\
{[112]}\end{array}$ & $\begin{array}{l}\text { Rabbits } \\
\text { tibia }\end{array}$ & $\begin{array}{l}\text { electrospun PLLA } \\
\text { nanofibrous membrane } \\
\quad+/ \text { - collagen }\end{array}$ & $\begin{array}{l}\text { Large bony defects } \\
\text { Three groups: a nanofiber-reinforced bilayer } \\
\text { membrane, a nanofibrous membrane, or a } \\
\text { collagenous membrane alone }\end{array}$ & $\begin{array}{c}\text { At three and six weeks Radiological } \\
\text { and histological }\end{array}$ & $\begin{array}{l}\text { Bilayer membrane group had more bony tissue } \\
\text { formation at thre weeks. At six weeks, only the } \\
\text { bilayer membrane-treated bone defects displayed } \\
\text { better regeneration of cortical bone tissue. Other } \\
\text { groups: defects filled with spongy bone-like tissue. }\end{array}$ \\
\hline $\begin{array}{l}\text { Lysiak- } \\
\text { Drwal } \\
2008 \\
{[113]}\end{array}$ & $\begin{array}{l}\text { Rabbits } \\
\text { femur }\end{array}$ & collagen & $\begin{array}{c}\text { A } 5 \text { mm in diameter defect created transcutaneously } \\
\text { Group I: control, left to heal spontaneously } \\
\text { Group II (BOC+BG): filled with Bio-Oss Collagen and } \\
\text { Bio Gide Perio membrane } \\
\text { Group III: BOC and platelet-rich plasma }\end{array}$ & $\begin{array}{c}\text { At one and three months } \\
\text { Histological }\end{array}$ & $\begin{array}{c}\text { Greater number of bone trabeculas after } \\
\text { implantation in groups II and III compared to } \\
\text { control. }\end{array}$ \\
\hline $\begin{array}{l}\mathrm{He} \\
2007 \\
{[62]}\end{array}$ & $\begin{array}{l}\text { Rabbits } \\
\text { tibia }\end{array}$ & $\begin{array}{l}\text { calcium alginate film } \\
\text { (CAF) versus collagen or } \\
\text { no membrane }\end{array}$ & $\begin{array}{l}\text { Circular bone } 5 \mathrm{~mm} \text { diameter defects } \\
\text { CAF versus collagen versus no membranes }\end{array}$ & $\begin{array}{l}\text { At one, two, four, six, and eight } \\
\text { weeks } \\
\text { Gross evaluation, radiological, } \\
\text { histological, immuno-histochemical, } \\
\text { and an image pattern analysis } \\
\text { system }\end{array}$ & $\begin{array}{c}\text { CAF induced dense bone formation, whereas CM } \\
\text { induced less new bone, and the blank control sites } \\
\text { even less. }\end{array}$ \\
\hline $\begin{array}{l}\text { Kong } \\
2007 \\
{[82]}\end{array}$ & $\begin{array}{l}\text { Rabbit } \\
\text { fibula }\end{array}$ & chitosan membrane & $\begin{array}{l}5 \mathrm{~mm} \text { defect filled with a porous nano- } \\
\text { hydroxyapatite-chitosan composite multilayer } \\
\text { scaffold }\end{array}$ & $\begin{array}{c}\text { At } 12 \text { weeks } \\
\text { Radiological and histological }\end{array}$ & $\begin{array}{l}\text { Composite membranes are implanted into a fibular } \\
\text { defect to evaluate the osteoconductivity and the } \\
\text { efficacy as a barrier to fibrous tissue ingrowth: } \\
\text { affluent blood vessels and bone formation found in } \\
\text { the center of the scaffold and little fibrous tissue } \\
\text { noted within the defect. }\end{array}$ \\
\hline $\begin{array}{l}\text { Gerbi } \\
2005 \\
{[114]}\end{array}$ & $\begin{array}{l}\text { Rats } \\
\text { Femur }\end{array}$ & $\begin{array}{l}\text { decalcified cortical } \\
\text { osseous membrane } \\
\text { [GenDerms]) +/- Laser } \\
\text { irradiation }\end{array}$ & $\begin{array}{c}\text { Surgical bone defects, five groups: } \\
\text { Group I (control); Group II (Gen-ox: Iyophilized } \\
\text { bovine bone organic matrix) } \\
\text { Group III (Gen-ox + Laser); } \\
\text { Group IV (Gen-ox + Gen-derm); } \\
\text { Group V (Gen-ox + Gen-derm + Laser) }\end{array}$ & $\begin{array}{l}\text { At } 15,21 \text {, and } 30 \text { days. } \\
\text { Histological assessment. }\end{array}$ & $\begin{array}{l}\text { Improved amount of collagen fibers at early stages } \\
\text { of the bone healing ( } 15 \text { days) and increased amount } \\
\text { of well organized bone trabeculae at } 30 \text { days on } \\
\text { irradiated animals compared to non irradiated ones. }\end{array}$ \\
\hline $\begin{array}{l}\text { Nasser } \\
2005 \\
{[115]}\end{array}$ & $\begin{array}{l}\text { Rabbits } \\
\text { radius }\end{array}$ & $\begin{array}{c}\text { two types: } \\
\text { - non-resorbable ethyl } \\
\text { cellulose membrane } \\
\text { (EC, N-type, Hercules Inc., } \\
\text { Delaware) } \\
\text { - resorbable chitosan } \\
\text { membrane }(\mathrm{CH} \text {, poly(D- } \\
\text { glucosamine), Aldrich) }\end{array}$ & $\begin{array}{l}1 \mathrm{~cm} \text { segmental radial defect } \\
\text { (2.5 times the radial bone diameter) }\end{array}$ & $\begin{array}{c}\text { Radiological } \\
\text { Every two weeks for an eight-week } \\
\text { period. } \\
\text { Bone density in the different } \\
\text { osteotomy } \\
\text { quadrants } \\
\text { Histological evaluation (scoring } \\
\text { system) } \\
\text { Four rabbits at two week intervals }\end{array}$ & $\begin{array}{c}\text { EC group: an increase in the new bone density was } \\
\text { apparent in all quadrants during the first four weeks, } \\
\text { followed by a sharp decline in bone density. } \\
\text { CH group: different biological behavior, lesser } \\
\text { increment in bone density in the first four weeks } \\
\text { but continued throughout the eight weeks. } \\
\text { Possible cause: degradation of membrane products } \\
\text { and foreign body reaction. } \\
\text { Based on histological findings: EC membranes are } \\
\text { better osteoinducers. } \\
\text { Radiological findings: CH membranes are better } \\
\text { osteoconductors. }\end{array}$ \\
\hline
\end{tabular}


Table 4 Summary of studies using resorbable membranes for long bone defects in small animal models (Continued)

\begin{tabular}{|c|c|c|c|c|c|}
\hline $\begin{array}{l}\text { Moore } \\
2004 \\
{[116]}\end{array}$ & $\begin{array}{l}\text { Rats } \\
\text { femur }\end{array}$ & $\begin{array}{l}\text { fresh, morselized porcine } \\
\text { small intestine } \\
\text { submucosa (SIS) used as } \\
\text { preformed tubular SIS } \\
\text { grafts }\end{array}$ & $\begin{array}{l}\text { Critical length segmental defects } \\
\text { four groups: unfilled or filled with morselized } \\
\text { cancellous bone, or spanned with intramedullary } \\
\text { tubes or periosteal sleeves fabricated from SIS }\end{array}$ & $\begin{array}{l}\text { Radiological (biweekly) } \\
\text { At } 12 \text { weeks histological, and } \\
\text { mechanical testing }\end{array}$ & $\begin{array}{l}\text { New bone formation in all defects treated with } \\
\text { cancellous bone. Fibrous tissue and no bone } \\
\text { formation in defects left unfilled or treated with SIS } \\
\text { SIS persisted at twelve weeks. } \\
\text { Cellular response to SIS: mild mononuclear infiltrate } \\
\text { in the loose or delaminated superficial layers of the } \\
\text { tubes and sleeves, with few cells in the deeper } \\
\text { layers. } \\
\text { The ability of SIS to support or stimulate growth of } \\
\text { bone across a critical length segmental bone defect } \\
\text { is doubted. }\end{array}$ \\
\hline $\begin{array}{l}\operatorname{lp} \\
2002 \\
{[117]}\end{array}$ & $\begin{array}{l}\text { Rabbit } \\
\text { radii }\end{array}$ & $\begin{array}{l}\text { poly(L/DL-lactide) } \\
\text { membrane or sponge } \\
\text { (bioabsorbable) }\end{array}$ & $\begin{array}{l}\text { Segmental defect, four groups: } \\
\text { I: untreated + plaster, } \\
\text { II: plate fixation } \\
\text { III: membrane + plate fixation } \\
\text { IV: sponge + plate fixation }\end{array}$ & $\begin{array}{c}\text { Radiological } \\
\text { At eight weeks histological }\end{array}$ & $\begin{array}{c}\text { Group I + II: no healing } \\
\text { Group II: healing } \\
\text { Group IV: more abundant healing than III }\end{array}$ \\
\hline $\begin{array}{l}\text { Ueyama } \\
2002 \\
{[60]}\end{array}$ & Rat tibia & $\begin{array}{l}\text { alginate membrane } \\
\text { (bioabsorbable) }\end{array}$ & $\begin{array}{c}\text { Calcium chloride aqueous solution dropped into the } \\
\text { bone defect, which is filled with sodium alginate } \\
\text { aqueous solution. }\end{array}$ & $\mathrm{n} / \mathrm{a}$ & $\begin{array}{l}\text { Evaluation of short-term biocompatibility of alginate } \\
\text { membrane. The healing process in bone defects } \\
\text { covered with an alginate membrane was delayed in } \\
\text { comparison with that of controls; however, the } \\
\text { defect was restored to nearly original condition. } \\
\text { In contrast, in the controls, bone defect repairs } \\
\text { exhibited partitioning as a result of connective tissue } \\
\text { involvement. } \\
\text { A relation between the sodium alginate } \\
\text { concentration and the rate of absorption of the } \\
\text { sodium alginate membrane was noted. } \\
\text { No inflammatory response around the alginate } \\
\text { membrane. }\end{array}$ \\
\hline $\begin{array}{l}\text { Matsuzaka } \\
2001 \\
{[118]}\end{array}$ & Rats tibia & $\begin{array}{c}\text { ePTFE } \\
\text { (non-resorbable) }\end{array}$ & $\begin{array}{c}\text { e-PTFE groups } \\
\text { control groups (without membrane) }\end{array}$ & $\begin{array}{c}\text { Histological } \\
\text { At six, eight, or ten days using } \\
\text { immunohistochemistry and } \\
\text { confocal laser scanning microscopy } \\
\text { to investigate new bone } \\
\text { mineralization }\end{array}$ & $\begin{array}{l}\text { The bone occupation ratio increased day by day, } \\
\text { but the experimental groups had significantly higher } \\
\text { ratios than control groups (without membrane) at } \\
\text { each of the time periods. More rapid mineralization } \\
\text { in the experimental groups vrsus controls. } \\
\text { GBR accelerates the migration of osteogenic cells, } \\
\text { the formation of new bone, and mineralization in } \\
\text { the defect created by the e-PTFE membrane. }\end{array}$ \\
\hline $\begin{array}{l}\text { Nyman } \\
2001 \\
{[119]}\end{array}$ & $\begin{array}{l}\text { Rabbits } \\
\text { radius }\end{array}$ & $\begin{array}{c}\text { ePTFE } \\
\text { (non-resorbable) }\end{array}$ & $\begin{array}{l}10 \mathrm{~mm} \text { diaphyseal defects } \\
\text { (both sides: test and control) } \\
\text { Test side: bone marrow ingrowth into the defects } \\
\text { was hindered or delayed (plugging the opening of } \\
\text { the cut bone ends with gutta-percha points; } \\
\text { plugging with Gelfoam; or by removing the bone } \\
\text { marrow by flushing with saline), in all defects: an } \\
\text { ePTFE membrane, shaped as a tube }\end{array}$ & $\begin{array}{l}\text { Regular radiological } \\
\text { At four to five months, histological }\end{array}$ & $\begin{array}{l}\text { Any attempts to delay or prevent bone marrow } \\
\text { ingrowth into the defects retard regeneration of } \\
\text { segmental long-bone defects. }\end{array}$ \\
\hline $\begin{array}{l}\text { Caiazza } \\
2000 \\
{[120]}\end{array}$ & $\begin{array}{l}\text { Rabbits } \\
\text { femur }\end{array}$ & $\begin{array}{l}\text { +/- resorbable collagen } \\
\text { membrane } \\
\text { (bovine Achilles tendon } \\
\text { collagen Type I) }\end{array}$ & $\begin{array}{c}\text { Ten hydroxyapatite-coated titanium fixtures inserted } \\
\text { within a created cortical defect, covered with a } \\
\text { resorbable membrane } \\
\text { Control: no membrane }\end{array}$ & $\begin{array}{c}\text { At } 60 \text { days } \\
\text { Tensile shear-stress at break testing } \\
\text { and histological }\end{array}$ & $\begin{array}{c}\text { Lower performance without membrane } \\
\text { Neoformed cortical bone present cervically around } \\
\text { implant was much thicker when a collagen } \\
\text { membrane was used. }\end{array}$ \\
\hline
\end{tabular}


Table 4 Summary of studies using resorbable membranes for long bone defects in small animal models (Continued)

Gogolewski Rabbits $10 \mathrm{~mm}$ diaphyseal segmental defects

Poly (Dits-lactide) and

2000 radius poly(L/DL-lactide)

[55] membranes

(bioabsorbable)

$\mathrm{mm}$ diaphyseal segmental defects

poly(L/DL-lactide)

$$
\text { eight weeks }
$$

At one year: complete bone regeneration in the defects covered with the poly(L/D-lactide)

to determine whether chemical composition of the

Histological at 3,6 and 12 months mbrane, only one animal with no regeneration membrane affected the bone healing in the defect. Control: previous study with same animal model and similar defects not covered with membranes or covered with poly(L-lactide) membranes

and one animal with pseudarthrosis.

Complete bone regeneration in all animals for the poly(L/DL-lactide) membrane (one animal died during surgery).

The quality of the interface between the new bone and the membrane seemed to be affected by the chemical structure of the polylactides used for

membranes preparation. The differences in chemical composition of the polylactide membranes did not have an evident effect on the bone regeneration process in segmental defects of the rabbit radii.

\begin{tabular}{|c|c|c|c|}
\hline $\begin{array}{c}\text { Ishikawa } \\
1999 \\
{[121]}\end{array}$ & Rats tibia & alginate membrane & $\begin{array}{l}3 \mathrm{~mm} \times 10 \mathrm{~mm} \text { bicortical bone defect filled with } \\
0.5,1.0, \text { or } 1.5 \% \mathrm{Na} \text {-Alg aqueous solution, then } 3 \% \\
\text { calcium chloride aqueous solution was dropped on } \\
\text { the Na-Alg solution to form an alginate membrane } \\
\text { four groups: (a) control group (no solutions) } \\
\text { (b) alginate membrane with } 0.5 \% \mathrm{Na} \text {-Alg solution } \\
\text { (c) alginate membrane with } 1.0 \% \mathrm{Na} \text {-Alg solution } \\
\text { (d) alginate membrane with } 1.5 \% \mathrm{Na} \text {-Alg solution }\end{array}$ \\
\hline
\end{tabular}

Histological

At four weeks tissue.

$0.5 \% \mathrm{Na}$-Alg solution: part of the alginate membrane had disappeared and connective tissue had begun to grow in the bone defect.

1.0 or $1.5 \%$ Na-Alg solution: the alginate membrane prevented any ingress of connective tissue to the bone defect, and the bone defect was reconstructed with new bone. At this stage, the alginate membrane still was observed, and the amount of unabsorbed alginate was larger for higher

concentrations of $\mathrm{Na}$-Alg aqueous solution. No inflammatory response was observed around the alginate membrane.

\begin{tabular}{ccccc}
\hline Suckow & Rats & small intestinal & The defect was either left unfilled or implanted with & Radiographically and histologically \\
1999 & radius & submucosa (SIS) & SIS, demineralized cortical bone (DMCB), or & after 3, 6, 12, and 24 weeks. \\
{$[122]$} & & & ovalbumin.
\end{tabular}

Tissue remodelling within the defect was evident by week three in SIS- and DMCB-treated rats. Fill characterized initially by infiltration of mononu was characterized initially by infitration of mononuclear cells and extracellular material in SIS-implanted rats
and multifocal remodelling bone particles and cartilage formation in DMCB-implanted rats.

Cartilage was observed as early as three weeks and bone as early as six weeks in SIS-implanted rats. Filling of the defect arose from multiple foci in DMCB-implanted rats, but was contiguous with and parallel to the ulnar shaft in SIS-implanted rats, suggesting that defect repair by SIS may be conductive rather than inductive. Rats in which the defect was left unfilled demonstrated slow but progressive filling of the defect, characterized by mononuclear cell infiltrates and fibrous extracellular material. SIS facilitated rapid filling of a long-bone defect. 


\begin{tabular}{|c|c|c|c|c|c|}
\hline $\begin{array}{l}\text { Meinig } \\
1997 \\
{[123]}\end{array}$ & $\begin{array}{l}\text { Minipigs } \\
\text { radius }\end{array}$ & $\begin{array}{l}\text { polymer membranes: } \\
\text { poly(L/DL-lactide) and } \\
\text { poly(D-lactide) } \\
\text { (bioabsorbable) }\end{array}$ & $\begin{array}{c}2.5 \text { to } 3 \mathrm{~cm} \text { mid-diaphyseal defect } \\
\text { five groups: (a) poly(L/DL-lactide), } \\
\text { (b) poly(L/DL-lactide)-CaCO3, } \\
\text { (c) poly(D-lactide), } \\
\text { (d) poly(D-lactide)-CaCO3, } \\
\text { (e) untreated defect } \\
\text { Ulna left intact and no adjunctive internal or external } \\
\text { fixation }\end{array}$ & $\begin{array}{l}\text { Radiological (biweekly) } \\
\text { At } 12 \text { weeks, histologic and } \\
\text { microradiographic evaluation }\end{array}$ & $\begin{array}{l}\text { The bone defects covered with membranes were } \\
\text { completely reconstituted by six to eight weeks. } \\
\text { Untreated defects healed with less bone formation } \\
\text { and in a more disorganized pattern. Histologic } \\
\text { evaluation of the implants demonstrated that the } \\
\text { entire lumen of the implant was filled with bone, } \\
\text { with some periosteal bone formation occurring on } \\
\text { the outer surface of the membrane. Direct } \\
\text { apposition of bone onto the membrane surface or } \\
\text { minimal fibrous tissue interposition between } \\
\text { membrane and new bone. No foreign body or } \\
\text { adverse reaction to the membrane. }\end{array}$ \\
\hline $\begin{array}{l}\text { Lu } \\
1996 \\
{[124]}\end{array}$ & $\begin{array}{l}\text { Rabbits } \\
\text { radius }\end{array}$ & silicone membrane & $\begin{array}{l}\text { 10-mm defect on radius silicone membrane sutured } \\
\text { as a tube } \\
\begin{array}{c}\text { 10-mm defects were also produced on the control } \\
\text { sides. }\end{array}\end{array}$ & $\begin{array}{l}\text { At } 12 \text { weeks radiological, three- } \\
\text { point bending test, and histological }\end{array}$ & $\begin{array}{c}\text { By the 12th week, seven of ten experimental sides } \\
\text { were healed, two were healed with a connective } \\
\text { cartilage zone, and one was not healed. None of the } \\
\text { control was healed but the defect was occupied by } \\
\text { soft tissue. }\end{array}$ \\
\hline $\begin{array}{l}\text { Pineda } \\
1996 \\
{[76]}\end{array}$ & $\begin{array}{l}\text { Rabbits } \\
\text { radius }\end{array}$ & $\begin{array}{c}\text { poly(L-lactide) } \\
\text { membranes of various } \\
\text { pore sizes } \\
\text { (microporous, medium } \\
\text { pore size (10 to } 20 \\
\text { microns), and large pore } \\
\text { size (20 to } 200 \text { microns) } \\
\text { (bioabsorbable) }\end{array}$ & $\begin{array}{l}10 \mathrm{~mm} \text { diaphyseal defect } \\
\text { No internal fixation (assumption that the intact ulna } \\
\text { splints the radius adequately) }\end{array}$ & $\begin{array}{l}\text { Radiological at two and four weeks } \\
\text { and six months }\end{array}$ & $\begin{array}{c}\text { Bone regeneration in the majority of cases, } \\
\text { regardless of pore size. } \\
\text { Some differences in the intensity of the bone } \\
\text { regeneration process. At two weeks, bone formation } \\
\text { seen in all animals, but at six months five rabbits of } \\
\text { five, four rabbits of five, and three rabbits of five } \\
\text { implanted respectively with microporous, medium } \\
\text { pore-size and large pore-size membrane showed } \\
\text { complete regeneration of the defect. }\end{array}$ \\
\hline $\begin{array}{l}\text { Nyman } \\
1995 \\
{[125]}\end{array}$ & $\begin{array}{l}\text { Rabbits } \\
\text { radius }\end{array}$ & $\begin{array}{l}\text { ePTFE membrane } \\
\text { (non-resorbable) }\end{array}$ & $\begin{array}{l}7 \text { to } 10 \mathrm{~mm} \text { segmental diaphyseal defects } \\
\text { Study group: membrane formed as a tube } \\
\text { Control: contralateral side with no membrane }\end{array}$ & $\begin{array}{l}\text { Radiological (obtained repeatedly) } \\
\text { and histological at } 13 \text { or } 27 \text { weeks }\end{array}$ & $\begin{array}{c}\text { Control group: some early subperiosteal callus } \\
\text { formation and non-union of the defects at six } \\
\text { weeks. } \\
\text { Study group: subperiosteal bone formation at the } \\
\text { bone ends first observed at two weeks. At nine } \\
\text { weeks, a thin cortical bone bridged the defect along } \\
\text { the inner surface of the membrane. } \\
\text { Histology: an interrupted line of thin, cortical bone } \\
\text { was observed along the inner surface of the barrier } \\
\text { membrane. Fatty bone marrow occupied the central } \\
\text { and largest volume of the defect. }\end{array}$ \\
\hline $\begin{array}{c}\text { Farso } \\
\text { Nielsen } \\
1992 \\
{[126]}\end{array}$ & $\begin{array}{l}\text { Rabbits } \\
\text { radius }\end{array}$ & $\begin{array}{l}\text { polyurethane membrane } \\
\text { (bioabsorbable) }\end{array}$ & $\begin{array}{l}1 \mathrm{~cm} \text { segmental, osteoperiosteal defects } \\
\text { Study group: membrane formed as a tube } \\
\text { versus untreated control }\end{array}$ & $\begin{array}{c}\text { At five weeks } \\
\text { Radiological and histological }\end{array}$ & $\begin{array}{c}\text { Controls: } 90 \% \text { non-union } \\
\text { Membrane-treated defects: all healed by forming } \\
\text { callus external to the membrane fusing the bone } \\
\text { fragments. Loose connective tissue was } \\
\text { predominant in the bone gap underneath the } \\
\text { membrane. }\end{array}$ \\
\hline
\end{tabular}


Table 5 Summary of studies using resorbable membranes for long bone defect reconstruction in large animal models

\begin{tabular}{|c|c|c|c|c|}
\hline $\begin{array}{c}\text { Author/ } \\
\text { Year } \\
\text { [ref] }\end{array}$ & $\begin{array}{l}\text { Animal } \\
\text { model }\end{array}$ & Type of membrane & Study design & $\begin{array}{l}\text { Assessment of bone } \\
\text { regeneration }\end{array}$ \\
\hline $\begin{array}{c}\text { Rhodes } \\
2010 \\
{[127]}\end{array}$ & $\begin{array}{l}\text { Dogs } \\
\text { humerus }\end{array}$ & Hyaluronan (Hyalonect) & $\begin{array}{l}\text { Periosteal reconstruction of bone } \\
\text { defects filled with a variety of } \\
\text { conventional bone filling } \\
\text { compounds. }\end{array}$ & Histological at six weeks \\
\hline
\end{tabular}

Hyalonect was shown to allow the regeneration of bone within the humeral defects while preventing fibrotic tissue in-growth, and allowing regeneration of tissue which, by six weeks, had begun to resemble natural periosteal tissue.

\begin{tabular}{|c|c|c|c|c|}
\hline $\begin{array}{l}\text { Oh } \\
2006 \\
{[128]}\end{array}$ & $\begin{array}{c}\text { Dogs } \\
\text { humerus }\end{array}$ & $\begin{array}{l}\text { betatricalcium phosphate } \\
\text { and poly L-lactide-co- } \\
\text { glycolide-coepsilon- } \\
\text { caprolactone (TCP/PLGC) }\end{array}$ & $\begin{array}{c}\text { Partial bone defects } \\
\text { (length: a quarter of the full } \\
\text { length of humerus, width: a } \\
\text { quarter of middle diameter of } \\
\text { the lateral aspect of humerus) } \\
\text { Control group: the contralateral } \\
\text { humerus }\end{array}$ & $\begin{array}{l}\text { Computed tomography } \\
(\mathrm{CT}) \text { at four and eight } \\
\text { weeks and histological }\end{array}$ \\
\hline $\begin{array}{c}\text { Beniker } \\
2003 \\
{[129]}\end{array}$ & $\begin{array}{l}\text { Pig } \\
\text { femur }\end{array}$ & $\begin{array}{l}\text { acellular dermal matrix } \\
\text { (GraftJacket Acellular } \\
\text { Periosteum Replacement } \\
\text { Scaffold) }\end{array}$ & Segmental bone defect & Histological at six wee \\
\hline
\end{tabular}

The result suggested that TCP/PLGC membrane is a good guided bone regeneration material to restore the original morphology of humerus in partial defect.

The scaffold protects the bone defect site as revealed by new bone formation within the margins of the defect and adjacent to the scaffold has been shown.

Minimal to no soft tissue invasion into the defect site. Dermal membrane material may be used as a scaffold for periosteum regeneration by allowing for cellular repopulation, revascularization, and bone defect restoration.

\begin{tabular}{|c|c|c|c|c|c|}
\hline $\begin{array}{l}\text { Gerber } \\
2002 \\
{[130]}\end{array}$ & $\begin{array}{l}\text { Sheep } \\
\text { Tibia }\end{array}$ & $\begin{array}{c}\text { bioabsorbable } \\
\text { polylactide membranes } \\
\text { (L/DL-lactide) (80\%-20\%) }\end{array}$ & $\begin{array}{c}\text { 7-cm diaphyseal defect } \\
\text { Resorbable polylactide } \\
\text { membranes }+ \text { ABG or a } \\
\text { vascularized periosteal flap. } \\
\text { four groups (fixation with a nail) }\end{array}$ & $\begin{array}{l}\text { Clinical + post-mortem } \\
\text { observation, radiological } \\
\text { post-op and then } \\
\text { weekly until week } 16 \text {. }\end{array}$ & $\begin{array}{c}\text { Polymeric membranes of adequate } \\
\text { composition and pore size combined } \\
\text { with } A B G \text { or vascularized periosteum } \\
\text { allow for rapid and stable defect } \\
\text { regeneration. }\end{array}$ \\
\hline $\begin{array}{l}\text { Gugala } \\
2002 \\
{[131]}\end{array}$ & $\begin{array}{l}\text { Sheep } \\
\text { tibia }\end{array}$ & $\begin{array}{c}\text { bioabsorbable } \\
\text { polylactide membranes, } \\
\text { with or without } \\
\text { perforations, } \\
\text { single or double-tube } \\
\text { designs }\end{array}$ & $\begin{array}{l}\text { six groups: Polylactide } \\
\text { membranes } \\
\text { Single or double-tube designs } \\
\text { +/_ cancellous bone grafting }\end{array}$ & $\begin{array}{c}\text { Radiological (X-rays and } \\
\text { CT) and histological at } \\
16 \text { weeks. }\end{array}$ & $\begin{array}{c}\text { In groups without bone grafting non- } \\
\text { union developed and persisted until } 16 \\
\text { weeks. Defect healing was only } \\
\text { observed when ABG was used along } \\
\text { with the single or double microporous- } \\
\text { perforated membranes. (new bone } \\
\text { formation by 'creeping substitution' of } \\
\text { the graft) }\end{array}$ \\
\hline $\begin{array}{l}\text { Gugala } \\
1999 \\
{[132]}\end{array}$ & $\begin{array}{l}\text { Sheep } \\
\text { tibia }\end{array}$ & poly(LDL-lactide) & $\begin{array}{l}4 \mathrm{~cm} \text { diaphyseal segmental } \\
\text { defects } \\
\text { 1) a single microporous } \\
\text { membrane } \\
\text { 2) a microporous internal } \\
\text { membrane, and a membrane on } \\
\text { the outer surface of the cortex } \\
\text { (external membrane) } \\
\text { 3) an external membrane laser- } \\
\text { perforated ( } 800 \text { to } 900 \\
\text { micrometers openings) } \\
\text { 4) ABG and a single perforated } \\
\text { membrane } \\
\text { 5) one perforated internal } \\
\text { membrane into the medullary } \\
\text { cavity and another membrane } \\
\text { on the outer surface of the } \\
\text { cortex } \\
\text { 6) as Group } 5 \text { + ABG between } \\
\text { the two membranes }\end{array}$ & $\begin{array}{l}\text { Radiological and } \\
\text { histological }\end{array}$ & $\begin{array}{l}\text { No bone healing in Groups 1, 2, 3, and } \\
\text { 5. Only in Groups } 4 \text { and } 6 \text { the defects } \\
\text { healed. In Group 4, new bone was } \\
\text { dispersed across the 'medullary canal' } \\
\text { formed by the membrane. In Group 6, } \\
\text { the new bone had grown into the } \\
\text { space between the outer and inner } \\
\text { membranes, forming the 'neocortex'. } \\
\text { The resorbable polymeric implant } \\
\text { consisting of two concentric perforated } \\
\text { membranes (the tube-in-tube implant) } \\
\text { used in combination with cancellous } \\
\text { bone graft to treat segmental } \\
\text { diaphyseal defects allows for the } \\
\text { reconstitution of the 'neocortex' with } \\
\text { well-defined thickness. }\end{array}$ \\
\hline
\end{tabular}


Table 6 Summary of clinical studies with bioresorbable membranes for reconstruction of segmental mandibular defects

\begin{tabular}{|c|c|c|c|c|c|c|c|c|c|}
\hline $\begin{array}{l}\text { Author/ } \\
\text { Year } \\
\text { [ref] }\end{array}$ & $\begin{array}{l}\text { Study } \\
\text { design }\end{array}$ & $\begin{array}{l}\text { No. } \\
\text { of } \\
\text { pts }\end{array}$ & Mandibular reconstruction & $\begin{array}{l}\text { Defect } \\
\text { size }\end{array}$ & Etiology & $\begin{array}{l}\text { Type of } \\
\text { membrane }\end{array}$ & Graft & $\begin{array}{l}\text { Type of } \\
\text { fixation }\end{array}$ & Outcome \\
\hline $\begin{array}{l}\text { Kinoshita } \\
2004 \\
{[33]}\end{array}$ & $\begin{array}{l}\text { case series } \\
\text { (1995 to } \\
\text { 2001) }\end{array}$ & 62 & $\begin{array}{c}\text { Mandibulectomy (segmental } \\
\text { defect and } \\
\text { hemimandibulectomy) }\end{array}$ & - & $\begin{array}{c}\text { malignant (22) and benign (30) tumors, cysts } \\
\text { (5), osteomyelitis (2), alveolar atrophy (1) } \\
\text { trauma (2) }\end{array}$ & $\begin{array}{l}\text { Absorbable } \\
\text { PLLA mesh }\end{array}$ & $\begin{array}{c}\text { Autologous } \\
\text { cancellous } \\
\text { bone graft } \\
\text { + bone } \\
\text { marrow }\end{array}$ & $\begin{array}{l}+/- \\
\text { stainless } \\
\text { steel wires }\end{array}$ & $\begin{array}{c}\text { At six months post-operation: } \\
\text { Excellent (markedly effective) } \\
56.5 \% \\
\text { Good (effective) } 27.4 \% \\
\text { Poor (not effective) } 16.1 \% \\
\text { X-ray of the regenerated bone: } \\
0 \text { to } 10 \% \text { bone resorption in } 31 \\
\text { cases } \\
10 \% \text { to } 20 \% \text { in six cases } \\
20 \% \text { to } 30 \% \text { in one case }\end{array}$ \\
\hline $\begin{array}{l}\text { Kinoshita } \\
2000 \\
{[133]}\end{array}$ & $\begin{array}{l}\text { case series } \\
\text { (1995 to } \\
\text { 1998) }\end{array}$ & 41 & $\begin{array}{l}\text { Segmental defect or large } \\
\text { partial defects } \\
\text { mandibulectomy }\end{array}$ & - & malignant (19) and benign (22) tumors & & & - & $\begin{array}{c}\text { Excellent: 19/41 (46.3\%) } \\
\text { Good 13/41 (31.7\%) } \\
\text { Poor 9/41 (22.2\%) (local } \\
\text { infection) } \\
\text { 86.5\% Success rate } \\
\text { Five years: no problems from } \\
\text { PLLA and good } \\
\text { osseointegration }\end{array}$ \\
\hline $\begin{array}{l}\text { Kinoshita } \\
1996 \\
{[57]}\end{array}$ & case series & 2 & $\begin{array}{l}\text { Segmental defect or large } \\
\text { partial defect }\end{array}$ & $\begin{array}{l}\text { right to } \\
\text { left molar } \\
\text { areas }\end{array}$ & tumor & & & $\begin{array}{l}\text { stainless } \\
\text { steel wires }\end{array}$ & $\begin{array}{l}\text { At three months: full bone } \\
\text { regeneration }\end{array}$ \\
\hline
\end{tabular}


Table 7 Summary of clinical studies with bioabsorbable membranes for reconstruction of long bone defects

\begin{tabular}{|c|c|c|c|c|c|c|c|c|c|c|}
\hline $\begin{array}{l}\text { Author/ } \\
\text { Year } \\
\text { [ref] }\end{array}$ & $\begin{array}{l}\text { Study } \\
\text { design }\end{array}$ & $\begin{array}{l}\text { No of } \\
\text { patients }\end{array}$ & Site & $\begin{array}{l}\text { Size of } \\
\text { defect }\end{array}$ & Etiology & $\begin{array}{l}\text { Type of } \\
\text { membrane }\end{array}$ & Graft & $\begin{array}{l}\text { Type of } \\
\text { fixation }\end{array}$ & Evaluation & Outcome \\
\hline $\begin{array}{l}\text { Meining } \\
2010[13]\end{array}$ & $\begin{array}{l}\text { case } \\
\text { series }\end{array}$ & Six & $\begin{array}{l}\text { Tibia } \\
\text { (five) } \\
\text { Femur } \\
\text { (one) }\end{array}$ & $\geq C S D$ & Trauma & $\begin{array}{l}\text { poly(L/DL-lactide) } \\
80 / 20 \% \\
\text { membranes with } \\
50 \text { to } 70 \\
\mu \mathrm{m} \text { pore size }\end{array}$ & RIA, ICBG & $\begin{array}{l}\text { IMN, } \\
\text { plating }\end{array}$ & X-rays & $\begin{array}{l}\text { Healing } \\
\text { one case: re-grafting after } 15 \\
\text { months }\end{array}$ \\
\hline $\begin{array}{c}1 p \\
2004 \\
{[134]}\end{array}$ & $\begin{array}{l}\text { case } \\
\text { series }\end{array}$ & Ten & $\begin{array}{l}\text { Not } \\
\text { reported }\end{array}$ & $\leq 6 \mathrm{~cm}$ & $\begin{array}{c}\text { Benign tumor, } \\
\text { Osteomyelitis and } \\
\text { trauma }\end{array}$ & & $\begin{array}{l}\text { polymeric scaffolds (sponges, } 450 \text { to } 700 \mu \mathrm{m} \\
\text { pore size) impregnated with bone marrow }\end{array}$ & $\begin{array}{l}\text { Not } \\
\text { reported }\end{array}$ & X-rays & $\begin{array}{l}\text { Presence of bone } \\
\text { regeneration and satisfactory } \\
\text { function }\end{array}$ \\
\hline
\end{tabular}

CSD, critical size defect; ICBG, iliac crest bone graft; IMN, intermedullary nailing; RIA, Reamer/lrrigator/Aspirator. 
to the different mechanical environment and less stressshielding of the fixation method used. Furthermore, it may also be explained by the different pathways of bone formation during the regeneration process due to the different embryological origin of the mandible (intramembranous ossification) compared to long bones (endochondral ossification) [135]. Considering these differences, the 'ideal' barrier membrane may be different for maxillofacial and orthopedic applications. For example, in the case of long bone defects, the 'ideal' membrane may require improved mechanical properties, a prolonged degradation period in the case of an absorbable membrane, and even different membrane porosity to allow vascular ingrowth from the surrounding soft tissues to optimize bone formation within the defect.

\section{Is current evidence adequate enough for use in humans?} Despite the fact that experimental evidence is well established and preliminary results from clinical studies are encouraging, there are still several points which prevent the safe and wide use of bioabsorbable membranes in humans. Healing potential in humans is different from that of animals and it occurs with various speeds in different bones (for example, mandible versus tibia), mainly due to the difference in vascularity and/or embryological origin. Therefore, the size of the segmental defect, able to be bridged using membranes, is not yet defined in humans [132]. Additionally, the load-bearing of different bones varies widely. Even if the bone gap may be successfully bridged by the regenerated bone, more evidence is required regarding the time it will be structurally mature to cover the functional requirements. Since load-bearing is vital for the formation and progression of bone formation, the load sharing capacity of the fixation method is of utmost importance. There is no information yet on how the new bone will develop and mature in various types of fixation methods, that is, which may be considered the optimal fixation for bone regeneration in humans.

Other major parameters affecting the efficacy of bone regeneration are the characteristics of the membranes, such as composition, thickness, porosity, and perforation size $[13,132]$. These variables are yet to be defined in humans, because they may act in conjunction with the healing potential of each bone and may be used to optimize bone regeneration in bones with low healing potential or with a deficient local environment.

\section{Specific considerations for orthopedic surgery}

Bioresorbable membranes are currently being used mainly for bone regeneration in oral and maxillofacial surgery in humans. However, their use in various orthopedic conditions also represents a field of interest, especially since the number of revision surgeries $[136,137]$ and limb salvage procedures is increasing $[138,139]$. For example, such membranes can be shaped as tubular chambers, thus preserving the continuity of the diaphysis for the repair of large diaphyseal bone defects [140]. By forming a 'tube-in-tube implant' using two concentric perforated membranes in combination with cancellous bone-graft, the reconstitution of the 'neocortex' with well-defined thickness was possible for the treatment of segmental diaphyseal defects in sheep tibiae [132]. Barrier membranes can also help to prevent significant absorption of the bone graft which is estimated to be up to $40 \%$ to $50 \%$ at four weeks [132] and seems to be due to absorption of bone that is not mechanically functioning [141]. As these membranes are radiolucent, they allow assessment of bone formation with conventional radiographs, CT or MRI [13], which is important for monitoring the regeneration process.

The evidence on the efficacy for cortical perforation (decortication) during GBR procedures in an effort to enhance bone formation remains controversial [142]. Studies have shown that cortical perforations increase the blood supply, facilitate angiogenesis, and allow access for progenitor cells from the bone marrow into the 'chamber' [142] whereas other studies showed that bone formation occurred from a non-injured cortical bone surface and that perforations were not required as they did not increase bone formation $[59,81]$. However, since there are no relevant human clinical studies and the relevant animal studies refer to mandibular defects, where local vascularity is superior to long bones, recommendations for additional bone decortication cannot be made for orthopedic GBR applications [142].

Finally, barrier membranes can be used in combination with bone grafting to augment osseointegration of orthopedic implants in the case of bone defects [143]. They may also be used for regeneration of other tissues with potential orthopedic applications, including tendon regeneration in rotator cuff repair, and post-traumatic nerve regeneration $[144,145]$, as the preliminary results are encouraging.

\section{Enhancement of bone regeneration and future research Biological augmentation of GBR with growth factors}

The interest in accelerating bone formation has led researchers to combine the membrane technique with osteoinductive or growth factors. Although the concept of additional biological enhancement of bone formation using growth factors that enhance proliferation, chemotaxis, and differentiation of osteogenic cells seems promising, results are often controversial. In a study evaluating the long-term outcome of oral implants placed in bone augmented with an allograft and a collagen membrane with or without the addition of recombinant-human bone morphogenetic protein-2 (rhBMP-2), no statistically significant differences were observed regarding the clinical and 
radiological outcomes [146]. On the contrary, numerous in vivo and in vitro studies have demonstrated improved bone formation when barrier membranes are loaded with platelet-derived growth factor (PDGF-BB) [147], basic fibroblast growth factor (FGF2) [148], and rhBMP-2 $[99,146,149]$.

Controversial evidence may be secondary to insufficiency in maintaining therapeutic concentrations of growth factors within bone defects due to rapid clearance and use of different delivery methods with supraphysiological non-standarized doses to obtain therapeutic efficacy [147]. Furthermore, current research usually evaluates one or a combination of two growth factors, which does not reflect the complex physiological process of bone formation. Research is ongoing to develop novel membranes and scaffolds with improved growth factor delivery systems to accelerate bone regeneration of critically-sized segmental bone defects with promising preliminary results [150]. Moreover, with a controlled spatiotemporal delivery of growth factors, adequate local protein concentrations can be improved and maintained for optimal regenerative efficacy, avoiding the currently used supraphysiologic doses and the concomitant adverse effects [151]. Finally, the optimal 'combination' of growth factors to be delivered has also to be established.

\section{Other strategies to improve bone regeneration}

Aiming to maximize or accelerate bone formation, supplementary strategies have been investigated in combination with barrier membranes and grafting. The potential use of low-level laser therapy (LLLT) has been evaluated as an adjunct for the regeneration of long bone defects in animal studies with positive results $[114,152]$. Supplementary treatment with hyperbaric oxygen has also shown synergistic regenerative effects in the past [153]. Additionally, preliminary results have shown that systemic administration of synthetic salmon calcitonin accelerated bone regeneration of the defects [154].

Research is ongoing to evaluate other methods to enhance bone regeneration, such as local administration of parathyroid hormone (PTH(1-34)) [155] and other growth factors [156] with promising preliminary results. Moreover, methods to optimize surface microtopography of the membranes have also been investigated to enhance bone formation at the cellular and molecular level [157]. Finally, in the future, improved barrier membranes can be used as part of the bone-tissue engineering approach combined with osteoprogenitor cells and/ or osteopromotive factors or even gene therapy, aiming to produce improved composite grafts [1]. Preliminary research is promising. For example, a novel threedimensional porous polymer poly( $\varepsilon$-caprolactone) (PCL) scaffold coated with adeno-associated virus encoding BMP2 using both ex vivo or in vivo gene therapy, led to increased bone ingrowth with increased mechanical properties in a rat femoral defect model [158].

\section{Conclusions}

The concept of barrier membranes for restoration of large bone defects has been developed in an effort to simplify their treatment by offering a sinlge-staged procedure and to overcome the limitations of current bone regeneration strategies. Research in this field is ongoing, with evidence being mainly gained from preclinical studies. Preliminary human studies have also shown promising results in maxillofacial, oral and orthopedic surgery. Nevertheless, before clinical applications can be recommended, future research should aim to generate and establish the 'ideal' barrier membrane. The additional use of bone-grafting materials within the membrane to fill the defect should also be evaluated, aiming to 'mimic' or even accelerate the normal process of bone formation. Finally, reproducible results and longterm observations with certified barrier membranes in animal models are required, and especially in large animal long bone defect models, as well as well-designed clinical studies to evaluate their safety, efficacy and costeffectiveness.

\section{Abbreviations}

ABG: autologous bone graft; ADM: acellular dermal matrix; BAMs: bioabsorbable membranes; BBM: bovine bone marrow; BCM: bovine collagen membrane; BG: bone graft; BMP: bone morphogenetic protein; BP: bovine pericardium; CAF: calcium alginate film; CaP: calcium phosphate; CM: collagen membrane; CCM: cross-linked collagen membrane; CSD: critical size defect; CT: computed tomography; DPPA: diphenylphosphorylazide; e-PTFE: expanded polytetrafluoroethylene; FGF: fibroblast growth factor; GBR: guided bone regeneration; GDF: growth differentiation factor; GTR: guided tissue regeneration; HA: hydroxyapatite; HFL: human fascia lata; HFT: human fascia temporalis; HP: human pericardium; ICBG: iliac crest bone graft; IMN: intramedullary nailing; MRI: magnetic resonance imaging; muCT: microcomputer tomography; $\mathrm{nHA}$ : nano-HA; PCL: poly( $\varepsilon$-caprolactone); PDLLCL: poly(dl-lactide-epsilon-caprolactone); PDGF: platelet-derived growth factor; PDTE: poly desaminotyrosyl-tyrosine-ethyl ester; PES: polyethersulfone; PLCL: poly lactide-co-e-caprolactone; PLGC: poly L-lactide-co-glycolide-coepsiloncaprolactone; PLLA: poly(L-lactide) acid; PLGA: poly(L-lactide)-co-glycolide acid; PRP: platelet-rich plasma; rh-BMP: recombinant human BMP; RIA: Ria/ Irrigator/Aspirator; SIS: small intestine submucosa; TCP: tricalcium phosphate.

\section{Author details}

'Department of Trauma and Orthopaedics, Academic Unit, Clarendon Wing, Leeds Teaching Hospitals NHS Trust, Great George Street, Leeds LS1 3EX, UK. ${ }^{2}$ Department of Trauma and Orthopedics, University of Milan, Orthopedic Institute, G. Pini, University of Milan, Italy. ${ }^{3}$ Leeds NIHR Biomedical Research Unit, Leeds Institute of Molecular Medicine, Beckett Street, Leeds, LS9 7TF UK.

\section{Authors' contributions}

$\mathrm{RD}$ and GIM contributed in the preparation of this manuscript in terms of literature review and writing-up. GMC and PVG contributed in the writing of specific sections of the manuscript and in revising it critically for important intellectual content. All authors read and have given final approval of the final manuscript.

\section{Competing interests}

The authors declare that they have no competing interests. 
Received: 10 November 2011 Accepted: 26 July 2012

Published: 26 July 2012

\section{References}

1. Dimitriou R, Jones E, McGonagle D, Giannoudis PV: Bone regeneration: current concepts and future directions. BMC Med 2011, 9:66.

2. Gugala Z, Lindsey RW, Gogolewski S: New approaches in the treatment of critical-size segmental defects in long bones. Macromol Symp 2007, 253:147-161

3. Schmitz JP, Hollinger JO: The critical size defect as an experimental model for craniomandibulofacial nonunions. Clin Orthop Relat Res 1986, 205:299-308.

4. Aronson J: Limb-lengthening, skeletal reconstruction, and bone transport with the llizarov method. J Bone Joint Surg Am 1997, 79:1243-1258.

5. Bauer TW, Muschler GF: Bone graft materials. An overview of the basic science. Clin Orthop Relat Res 2000, 371:10-27.

6. Giannoudis PV, Dinopoulos H, Tsiridis E: Bone substitutes: an update. Injury 2005, 36(Suppl 3):S20-27

7. Giannoudis PV, Einhorn TA: Bone morphogenetic proteins in musculoskeletal medicine. Injury 2009, 40(Suppl 3):S1-3.

8. Pederson WC, Person DW: Long bone reconstruction with vascularized bone grafts. Orthop Clin North Am 2007, 38:23-35.

9. Masquelet $\mathrm{AC}$, Begue T: The concept of induced membrane for reconstruction of long bone defects. Orthop Clin North Am 2010, 41:27-37.

10. Pelissier P, Masquelet AC, Bareille R, Pelissier SM, Amedee J: Induced membranes secrete growth factors including vascular and osteoinductive factors and could stimulate bone regeneration. J Orthop Res 2004, 22:73-79.

11. Viateau V, Guillemin G, Calando Y, Logeart D, Oudina K, Sedel L, Hannouche D, Bousson V, Petite H: Induction of a barrier membrane to facilitate reconstruction of massive segmental diaphyseal bone defects: an ovine model. Vet Surg 2006, 35:445-452.

12. Giannoudis PV, Faour O, Goff T, Kanakaris N, Dimitriou R: Masquelet technique for the treatment of bone defects: tips-tricks and future directions. Injury 2011, 42:591-598.

13. Meinig RP: Clinical use of resorbable polymeric membranes in the treatment of bone defects. Orthop Clin North Am 2010, 41:39-47.

14. Retzepi M, Donos N: Guided bone regeneration: biological principle and therapeutic applications. Clin Oral Implants Res 2010, 21:567-576.

15. Gottlow J: Guided tissue regeneration using bioresorbable and nonresorbable devices: initial healing and long-term results. I Periodontol 1993, 64(11 Suppl):1157-1165.

16. Hurley L, Stinchfield F, Bassett A, Lyon W: The role of soft tissues in osteogenesis. An experimental study of canine spine fusions. J Bone Joint Surg Am 1959, 41:1243-1254.

17. Boyne PJ: Regeneration of alveolar bone beneath cellulose acetate filter implants. J Dent Res 1964, 43:827.

18. Boyne PJ: Restoration of osseous defects in maxillofacial casualties. J Am Dent Assoc 1969, 78:767-776.

19. Ogiso B, Hughes FJ, Melcher AH, McCulloch CA: Fibroblasts inhibit mineralised bone nodule formation by rat bone marrow stromal cells in vitro. J Cell Physiol 1991, 146:442-450.

20. Dahlin C, Linde A, Gottlow J, Nyman S: Healing of bone defects by guided tissue regeneration. Plast Reconstr Surg 1988, 81:672-676.

21. Pitaru S, Tal H, Soldinger M, Grosskopf A, Noff M: Partial regeneration of periodontal tissues using collagen barriers. Initial observations in the canine. J Periodontol 1988, 59:380-386.

22. Schenk RK, Buser D, Hardwick WR, Dahlin C: Healing pattern of bone regeneration in membrane-protected defects: a histologic study in the canine mandible. Int J Oral Maxillofac Implants 1994, 9:13-29.

23. McAllister BS, Haghighat K: Bone augmentation techniques. J Periodontol 2007, 78:377-396.

24. Nyman R, Magnusson M, Sennerby L, Nyman S, Lundgren D: Membraneguided bone regeneration. Segmental radius defects studied in the rabbit. Acta Orthop Scand 1995, 66:169-173.

25. Scantlebury TV: 1982-1992: a decade of technology development for guided tissue regeneration. J Periodontol 1993, 64(11 Suppl):1129-1137.

26. Aaboe M, Pinholt EM, Hjørting-Hansen E: Healing of experimentally created defects: a review. Br J Oral Maxillofac Surg 1995, 33:312-318.

27. Wiltfang J, Merten HA, Peters JH: Comparative study of guided bone regeneration using absorbable and permanent barrier membranes: a histologic report. Int J Oral Maxillofac Implants 1998, 13:416-421.
28. Marouf HA, El-Guindi HM: Efficacy of high-density versus semipermeable PTFE membranes in an elderly experimental model. Oral Surg Oral Med Oral Pathol Oral Radiol Endod 2000, 89:164-170.

29. Ostermann PA, Haase N, Rübberdt A, Wich M, Ekkernkamp A: Management of a long segmental defect at the proximal meta-diaphyseal junction of the tibia using a cylindrical titanium mesh cage. J Orthop Trauma 2002, 16:597-601.

30. Hardwick R, Hayes BK, Flynn C: Devices for dentoalveolar regeneration: an up-to-date literature review. J Periodontol 1995, 66:495-505.

31. Gielkens PF, Schortinghuis J, de Jong JR, Raghoebar GM, Stegenga B, Bos RR: Vivosorb, Bio-Gide, and Gore-Tex as barrier membranes in rat mandibular defects: an evaluation by microradiography and micro-CT. Clin Oral Implants Res 2008, 19:516-521.

32. Gielkens PF, Schortinghuis J, de Jong JR, Paans AM, Ruben JL, Raghoebar GM, Stegenga B, Bos RR: The influence of barrier membranes on autologous bone grafts. J Dent Res 2008, 87:1048-1052.

33. Kinoshita Y: Regenerative medicine for jawbone. JMAJ 2004, 47:294-297.

34. Thomaidis V, Kazakos K, Lyras DN, Dimitrakopoulos I, Lazaridis N, Karakasis D, Botaitis S, Agrogiannis G: Comparative study of 5 different membranes for guided bone regeneration of rabbit mandibular defects beyond critical size. Med Sci Monit 2008, 14:BR67-73.

35. Needleman IG, Worthington HV, Giedrys-Leeper E, Tucker RJ: Guided tissue regeneration for periodontal infra-bony defects. Cochrane Database Syst Rev 2006, 2:CD001724.

36. Sculean A, Nikolidakis D, Schwarz F: Regeneration of periodontal tissues: combinations of barrier membranes and grafting materials - biological foundation and preclinical evidence: a systematic review. J Clin Periodontol 2008, 35(8 Suppl):106-116.

37. Nakajima S, Fukuda T, Hasue M, Sengoku Y, Haraoka J, Uchida T: New technique for application of fibrin sealant: rubbing method devised to prevent cerebrospinal fluid leakage from dura mater sites repaired with expanded polytetrafluoroethylene surgical membranes. Neurosurgery 2001, 49:117-123.

38. Schmidmaier G, Baehr K, Mohr S, Kretschmar M, Beck S, Wildemann B: Biodegradable polylactide membranes for bone defect coverage: biocompatibility testing, radiological and histological evaluation in a sheep model. Clin Oral Implants Res 2006, 17:439-444.

39. Klaue $\mathrm{K}$, Knothe $\mathrm{U}$, Masquelet $\mathrm{A}$ : Effet biologique des membranes à corps etranger induites in situ sur la consolidation des greffes d'os spongieux. Rev Chir Orthop Suppl 1995, 70:109-110.

40. Patino MG, Neiders ME, Andreana S, Noble B, Cohen RE: Collagen as an implantable material in medicine and dentistry. J Oral Implantol 2002, 28:220-225.

41. Bunyaratavej $\mathrm{P}$, Wang HL: Collagen membranes: a review. J Periodontol 2001, 72:215-229.

42. von Arx T, Broggini N, Jensen SS, Bornstein MM, Schenk RK, Buser D: Membrane durability and tissue response of different bioresorbable barrier membranes: a histologic study in the rabbit calvarium. Int J Oral Maxillofac Implants 2005, 20:843-853.

43. Alpar B, Leyhausen G, Günay H, Geurtsen W: Compatibility of resorbable and nonresorbable guided tissue regeneration membranes in cultures of primary human periodontal ligament fibroblasts and human osteoblastlike cells. Clin Oral Investig 2000, 4:219-225.

44. Behring J, Junker R, Walboomers XF, Chessnut B, Jansen JA: Toward guided tissue and bone regeneration: morphology, attachment, proliferation, and migration of cells cultured on collagen barrier membranes. A systematic review. Odontology 2008, 96:1-11.

45. Rothamel D, Schwarz F, Sculean A, Herten M, Scherbaum W, Becker J: Biocompatibility of various collagen membranes in cultures of human PDL fibroblasts and human osteoblast-like cells. Clin Oral Implants Res 2004, 15:443-449.

46. Tal H, Kozlovsky A, Artzi Z, Nemcovsky CE, Moses O: Long-term biodegradation of cross-linked and non-cross-linked collagen barriers in human guided bone regeneration. Clin Oral Implants Res 2008, 19:295-302.

47. Lee CK, Koo KT, Kim TI, Seol YJ, Lee YM, Rhyu IC, Ku Y, Chung CP, Park YJ, Lee JY: Biological effects of a porcine-derived collagen membrane on intrabony defects. J Periodontal Implant Sci 2010, 40:232-238.

48. Coïc M, Placet V, Jacquet E, Meyer C: Mechanical properties of collagen membranes used in guided bone regeneration: a comparative study of three models. [Article in French]. Rev Stomatol Chir Maxillofac 2010, $111: 286-290$ 
49. Gupta KC, Ravi Kumar MN: Drug release behavior of beads and microgranules of chitosan. Biomaterials 2000, 21:1115-1119.

50. Klokkevold PR, Subar P, Fukayama H, Bertolami CN: Effect of chitosan on lingual hemostasis in rabbits with platelet dysfunction induced by epoprostenol. J Oral Maxillofac Surg 1992, 50:41-45.

51. Shin SY, Park HN, Kim KH, Lee MH, Choi YS, Park YJ, Lee YM, Ku Y, Rhyu IC, Han SB, Lee SJ, Chung CP: Biological evaluation of chitosan nanofiber membrane for guided bone regeneration. J Periodontol 2005, 76:1778-1784.

52. Lee EJ, Shin DS, Kim HE, Kim HW, Koh YH, Jang JH: Membrane of hybrid chitosan-silica xerogel for guided bone regeneration. Biomaterials 2009, 30:743-750.

53. Kung S, Devlin H, Fu E, Ho KY, Liang SY, Hsieh YD: The osteoinductive effect of chitosan-collagen composites around pure titanium implant surfaces in rats. J Periodontal Res 2011, 46:126-133.

54. Asikainen AJ, Noponen J, Lindqvist C, Pelto M, Kellomäki M, Juuti $H_{\text {, }}$ Pihlajamäki $H$, Suuronen R: Tyrosine-derived polycarbonate membrane in treating mandibular bone defects. An experimental study. J R Soc Interface 2006, 3:629-635.

55. Gogolewski S, Pineda L, Büsing CM: Bone regeneration in segmental defects with resorbable polymeric membranes: IV. Does the polymer chemical composition affect the healing process? Biomaterials 2000, 21:2513-2520.

56. Kaushiva A, Turzhitsky VM, Darmoc M, Backman V, Ameer GA: A biodegradable vascularizing membrane: a feasibility study. Acta Biomater 2007, 3:631-642.

57. Kinoshita Y, Kobayashi M, Fukuoka S, Yokoya S, Ikada Y: Functional reconstruction of the jaw bones using poly(l-lactide) mesh and autogenic particulate cancellous bone and marrow. Tissue Eng 1996, 2:327-341

58. Polimeni G, Koo KT, Pringle GA, Agelan A, Safadi FF, Wikesjo UM: Histopathological observations of a polylactic acid-based device intended for guided bone/tissue regeneration. Clin Implant Dent Relat Res 2008, 10:99-105.

59. Schliephake $H$, Kracht D: Vertical ridge augmentation using polylactic membranes in conjunction with immediate implants in periodontally compromised extraction sites: an experimental study in dogs. Int J Oral Maxillofac Implants 1997, 12:325-334.

60. Ueyama Y, Ishikawa K, Mano T, Koyama T, Nagatsuka H, Suzuki K, Ryoke K: Usefulness as guided bone regeneration membrane of the alginate membrane. Biomaterials 2002, 23:2027-2033.

61. Ueyama Y, Koyama T, Ishikawa K, Mano T, Ogawa Y, Nagatsuka H, Suzuki K: Comparison of ready-made and self-setting alginate membranes used as a barrier membrane for guided bone regeneration. J Mater Sci Mater Med 2006, 17:281-288.

62. He H, Huang J, Chen G, Dong Y: Application of a new bioresorbable film to guided bone regeneration in tibia defect model of the rabbits. $J$ Biomed Mater Res A 2007, 82:256-262.

63. Jianqi $H$, Hong $H$, Lieping S, Genghua G: Comparison of calcium alginate film with collagen membrane for guided bone regeneration in mandibular defects in rabbits. J Oral Maxillofac Surg 2002, 60:1449-1454.

64. Kim JH, Kim MK, Park JH, Won JE, Kim TH, Kim HW: Performance of Novel Nanofibrous Biopolymer Membrane for Guided Bone Regeneration within Rat Mandibular Defect. In Vivo 2011, 25:589-595.

65. Zhang J, Huang C, Xu Q, Mo A, Li J, Zuo Y: Biological properties of a biomimetic membrane for guided tissue regeneration: a study in rat calvarial defects. Clin Oral Implants Res 2010, 21:392-397.

66. Humber CC, Sándor GK, Davis JM, Peel SA, Brkovic BM, Kim YD, Holmes HI, Clokie CM: Bone healing with an in situ-formed bioresorbable polyethylene glycol hydrogel membrane in rabbit calvarial defects. Oral Surg Oral Med Oral Pathol Oral Radiol Endod 2010, 109:372-384.

67. Kothiwale SV, Anuroopa P, Gajiwala AL: A clinical and radiological evaluation of DFDBA with amniotic membrane versus bovine derived xenograft with amniotic membrane in human periodontal grade II furcation defects. Cell Tissue Bank 2009, 10:317-326.

68. Wu CA, Pettit AR, Toulson S, Grøndahl L, Mackie EJ, Cassady Al: Responses in vivo to purified poly(3-hydroxybutyrate-co-3-hydroxyvalerate) implanted in a murine tibial defect model. J Biomed Mater Res A 2009, 91:845-854.
69. Teng SH, Lee EJ, Wang P, Shin DS, Kim HE: Three-layered membranes of collagen/hydroxyapatite and chitosan for guided bone regeneration. J Biomed Mater Res B Appl Biomater 2008, 87:132-138.

70. Shabani I, Haddadi-Asl V, Soleimani M, Seyedjafari E, Babaeijandaghi F, Ahmadbeigi $\mathrm{N}$ : Enhanced infiltration and biomineralization of stem cells on collagen-grafted three-dimensional nanofibers. Tissue Eng Part A 2011, 17:1209-1218.

71. Berner A, Boerckel JD, Saifzadeh S, Steck R, Ren J, Vaquette C, Zhang JQ, Nerlich M, Guldberg RE, Hutmacher DW, Woodruff MA: Biomimetic tubular nanofiber mesh and platelet rich plasma-mediated delivery of BMP-7 for large bone defect regeneration. Cell Tissue Res 2012, 347:603-612.

72. Ereno C, Guimarães SA, Pasetto S, Herculano RD, Silva CP, Graeff CF, Tavano O, Baffa O, Kinoshita A: Latex use as an occlusive membrane for guided bone regeneration. J Biomed Mater Res A 2010, 95:932-939.

73. Tokuda S, Obata A, Kasuga T: Preparation of poly(lactic acid)/siloxane/ calcium carbonate composite membranes with antibacterial activity. Acta Biomater 2009, 5:1163-1168.

74. Zhang J, Xu Q, Huang C, Mo A, Li J, Zuo Y: Biological properties of an anti-bacterial membrane for guided bone regeneration: an experimental study in rats. Clin Oral Implants Res 2010, 21:321-327.

75. Chaturvedi R, Gill AS, Sikri P: Evaluation of the regenerative potential of $25 \%$ doxycycline-loaded biodegradable membrane vs biodegradable membrane alone in the treatment of human periodontal infrabony defects: a clinical and radiological study. Indian J Dent Res 2008, 19:116-123.

76. Pineda LM, Busing Mc, Mienig RP, Gogolewski S: Bone regeneration with resorbable polymeric membranes. Effect of pore size on bone healing process in large defects. J Biomed Mater Res 1996, 31:385-394.

77. Chvapil M, Holusa R, Kliment K, Stoll M: Some chemical and biological characteristics of a new collagen-polymer compound material. J Biomed Mater Res 1969, 3:315-332.

78. Taylor D, Smith F: Porous methyl methacrylate as an implant material. J Biomed Mater Res 1972, 6:467-479.

79. Klawitter J, Bagwell J, Weinstein A, Sauer B: An evaluation of bone growth into porous high density polyethylene. J Biomed Mater Res 1976, 10:311-323.

80. Spector M, Flemming W, Kreutner A: Bone growth into porous highdensity polyethylene. J Biomed Mater Res 1976, 10:595-603.

81. Gutta R, Baker RA, Bartolucci AA, Louis PJ: Barrier membranes used for ridge augmentation: is there an optimal pore size? J Oral Maxillofac Surg 2009, 67:1218-1225.

82. Kong L, Ao Q, Wang A, Gong K, Wang X, Lu G, Gong Y, Zhao N, Zhang X: Preparation and characterization of a multilayer biomimetic scaffold for bone tissue engineering. J Biomater App/ 2007, 22:223-239.

83. de Santana RB, de Mattos CM, Francischone CE, Van Dyke T: Superficial topography and porosity of an absorbable barrier membrane impacts soft tissue response in guided bone regeneration. J Periodontol 2010, 81:926-933.

84. Becker W, Becker B, McGuire M: Localized ridge augmentation using absorbable pins and e-PTFE barrier membranes: a new surgical technique. Case reports. Int J Periodont Restor Dent 1994, 14:48-61.

85. Jovanovic S, Nevins M: Bone formation utilizing titanium-reinforced barrier membranes. Int J Periodont Restor Dent 1995, 15:56-69.

86. Simion $M$, Trisi $P$, Piattelli $A$ : Vertical ridge augmentation using a membrane technique associated with osseointegrated implants. Int J Periodont Restor Dent 1994, 14:496-511.

87. Ducheyne $\mathrm{P}$, De Meester $\mathrm{P}$, Aernoudt E: Influence of a functional dynamic loading on bone ingrowth into surface pores of orthopedic implants. J Biomed Mater Res 1977, 11:811-838.

88. Heck D, Nakajima I, Kelly P, Chao E: The effect of load alteration on the biological and biomechanical performance of a titanium fiber-metal segmental prosthesis. J Bone Joint Surg Am 1986, 68:118-126.

89. Pilliar $\mathrm{R}$, Cameron $\mathrm{H}$, Welsh $\mathrm{R}$, Binnington $\mathrm{A}$ : Radiographic and morphologic studies of load-bearing porous-surfaced structured implants. Clin Orthop Relat Res 1981, 156:249-257.

90. Boerckel JD, Uhrig BA, Willett NJ, Huebsch N, Guldberg RE: Mechanical regulation of vascular growth and tissue regeneration in vivo. Proc Natl Acad Sci USA 2011, 108:E674-680.

91. Matsuo A, Chiba H, Takahashi H, Toyoda J, Abukawa H: Clinical application of a custom-made bioresorbable raw particulate hydroxyapatite/poly-L- 
lactide mesh tray for mandibular reconstruction. Odontology 2010, 98:85-88.

92. Amano Y, Ota M, Sekiguchi K, Shibukawa Y, Yamada S: Evaluation of a poly-l-lactic acid membrane and membrane fixing pin for guided tissue regeneration on bone defects in dogs. Oral Surg Oral Med Oral Pathol Oral Radiol Endod 2004, 97:155-163.

93. Lacroix D, Prendergast PJ: A mechano-regulation model for tissue differentiation during fracture healing: analysis of gap size and loading. J Biomech 2002, 35:1163-1171.

94. Stetzer K, Cooper G, Gassner R, Kapucu R, Mundell R, Mooney MP: Effects of fixation type and guided tissue regeneration on maxillary osteotomy healing in rabbits. J Oral Maxillofac Surg 2002, 60:427-436.

95. Kazakos K, Lyras DN, Thomaidis V, Agrogiannis G, Botaitis S, Drosos G, Kokka A, Verettas D: Application of PRP gel alone or in combination with guided bone regeneration does not enhance bone healing process: an experimental study in rabbits. J Craniomaxillofac Surg 2011, 39:49-53.

96. Hoogeveen EJ, Gielkens PF, Schortinghuis J, Ruben JL, Huysmans MC, Stegenga B: Vivosorb as a barrier membrane in rat mandibular defects. An evaluation with transversal microradiography. Int J Oral Maxillofac Surg 2009, 38:870-875.

97. He H, Yan W, Chen G, Lu Z: Acceleration of de novo bone formation with a novel bioabsorbable film: a histomorphometric study in vivo. $J$ Oral Pathol Med 2008, 37:378-382.

98. Zahedi S, Legrand R, Brunel G, Albert A, Dewé W, Coumans B, Bernard JP: Evaluation of a diphenylphosphorylazide-crosslinked collagen membrane for guided bone regeneration in mandibular defects in rats. J Periodontol 1998, 69:1238-1246.

99. Linde A, Hedner E: Recombinant bone morphogenetic protein-2 enhances bone healing, guided by osteopromotive e-PTFE membranes: an experimental study in rats. Calcif Tissue Int 1995, 56:549-553.

100. Zellin G, Gritli-Linde A, Linde A: Healing of mandibular defects with different biodegradable and non-biodegradable membranes: an experimental study in rats. Biomaterials 1995, 16:601-609.

101. Dahlin C, Sandberg E, Alberius P, Linde A: Restoration of mandibular nonunion bone defects. An experimental study in rats using an osteopromotive membrane method. Int I Oral Maxillofac Surg 1994, 23:237-242.

102. Kostopoulos L, Karring T: Guided bone regeneration in mandibular defects in rats using a bioresorbable polymer. Clin Oral Implants Res 1994, 5:66-74.

103. Sandberg E, Dahlin C, Linde A: Bone regeneration by the osteopromotion technique using bioabsorbable membranes: an experimental study in rats. J Oral Maxillofac Surg 1993, 51:1106-1114.

104. Jégoux F, Goyenvalle $E$, Cognet R, Malard O, Moreau F, Daculsi G, Aguado E: Mandibular segmental defect regenerated with macroporous biphasic calcium phosphate, collagen membrane, and bone marrow graft in dogs. Arch Otolaryngol Head Neck Surg 2010, 136:971-978.

105. Borges GJ, Novaes AB Jr, Grisi MF, Palioto DB, Taba M Jr, de Souza SL: Acellular dermal matrix as a barrier in guided bone regeneration: a clinical, radiographic and histomorphometric study in dogs. Clin Oral Implants Res 2009, 20:1105-1115.

106. Sverzut CE, Faria PE, Magdalena CM, Trivellato AE, Mello-Filho FV, Paccola CA, Gogolewski S, Salata LA: Reconstruction of mandibular segmental defects using the guided-bone regeneration technique with polylactide membranes and/or autogenous bone graft: a preliminary study on the influence of membrane permeability. J Oral Maxillofac Surg 2008, 66:647-656.

107. Bornstein MM, Bosshardt D, Buser D: Effect of two different bioabsorbable collagen membranes on guided bone regeneration: a comparative histomorphometric study in the dog mandible. J Periodontol 2007, 78:1943-1953.

108. Zubery Y, Goldlust A, Antoine Alves A, Nir E: Ossification of a novel crosslinked porcine collagen barrier in guided bone regeneration in dogs. $J$ Periodontol 2007, 78:112-121.

109. Peled M, Machtei EE, Rachmiel A: Osseous reconstruction using a membrane barrier following marginal mandibulectomy: an animal pilot study. J Periodontol 2002, 73:1451-1456.

110. Fritz ME, Jeffcoat MK, Reddy M, Koth D, Braswell LD, Malmquist J, Lemons J: Guided bone regeneration of large mandibular defects in a primate model. J Periodontol 2000, 71:1484-1491.
111. Bernabé PF, Melo LG, Cintra LT, Gomes-Filho JE, Dezan E Jr, Nagata MJ: Bone healing in critical-size defects treated with either bone graft, membrane, or a combination of both materials: a histological and histometric study in rat tibiae. Clin Oral Implants Res 2012, 23:384-388.

112. Cai YZ, Wang LL, Cai HX, Qi YY, Zou XH, Ouyang HW: Electrospun nanofibrous matrix improves the regeneration of dense cortical bone. Biomed Mater Res A 2010, 95:49-57.

113. Lysiak-Drwal K, Dominiak M, Solski L, Zywicka B, Pielka S, Konopka T, Gerber $\mathrm{H}$ : Early histological evaluation of bone defect healing with and without guided bone regeneration techniques: experimental animal studies. Postepy Hig Med Dosw (Online) 2008, 62:282-288.

114. Gerbi ME, Pinheiro AL, Marzola C, Limeira Júnior Fde A, Ramalho LM, Ponzi EA, Soares AO, Carvalho LC, Lima HV, Gonçalves TO: Assessment of bone repair associated with the use of organic bovine bone and membrane irradiated at $830 \mathrm{~nm}$. Photomed Laser Surg 2005, 23:382-388.

115. Nasser NJ, Friedman A, Friedman M, Moor E, Mosheiff R: Guided bone regeneration in the treatment of segmental diaphyseal defects: a comparison between resorbable and non-resorbable membranes. Injury 2005, 36:1460-1466.

116. Moore DC, Pedrozo HA, Crisco JJ, Ehrlich MG: Preformed grafts of porcine small intestine submucosa (SIS) for bridging segmental bone defects. J Biomed Mater Res A 2004, 69:259-266.

117. Ip WY: Polylactide membranes and sponges in the treatment of segmental defects in rabbit radii. Injury 2002, 33(Suppl 2):66-70.

118. Matsuzaka K, Shimono M, Inoue T: Characteristics of newly formed bone during guided bone regeneration: observations by immunohistochemistry and confocal laser scanning microscopy. Bull Tokyo Dent Coll 2001, 42:225-234.

119. Nyman R, Sennerby L, Nyman S, Lundgren D: Influence of bone marrow on membrane-guided bone regeneration of segmental long-bone defects in rabbits. Scand J Plast Reconstr Surg Hand Surg 2001, 35:239-246.

120. Caiazza S, Colangelo P, Bedini R, Formisano G, De Angelis G, Barrucci S: Evaluation of guided bone regeneration in rabbit femur using collagen membranes. Implant Dent 2000, 9:219-225.

121. Ishikawa K, Ueyama Y, Mano T, Koyama T, Suzuki K, Matsumura T: Selfsetting barrier membrane for guided tissue regeneration method: initial evaluation of alginate membrane made with sodium alginate and calcium chloride aqueous solutions. J Biomed Mater Res 1999, 47:111-115.

122. Suckow MA, Voytik-Harbin SL, Terril LA, Badylak SF: Enhanced bone regeneration using porcine small intestinal submucosa. J Invest Surg 1999, 12:277-287.

123. Meinig RP, Buesing CM, Helm J, Gogolewski S: Regeneration of diaphyseal bone defects using resorbable poly(L/DL-lactide) and poly(D-lactide) membranes in the Yucatan pig model. J Orthop Trauma 1997, 11:551-558.

124. Lu S, Zhang Z, Wang J: Guided bone regeneration in long bone. An experimental study. Chin Med J (Engl) 1996, 109:551-554.

125. Nyman R, Magnusson M, Sennerby L, Nyman S, Lundgren D: Membraneguided bone regeneration. Segmental radius defects studied in the rabbit. Acta Orthop Scand 1995, 66:169-173.

126. Farso Nielsen F, Karring T, Gogolewski S: Biodegradable guide for bone regeneration. Polyurethane membranes tested in rabbit radius defects. Acta Orthop Scand 1992, 63:66-69.

127. Rhodes NP, Hunt JA, Longinotti C, Pavesio A: In Vivo Characterization of Hyalonect, a Novel Biodegradable Surgical Mesh. J Surg Res 2011, 168: e31-38.

128. Oh T, Rahman MM, Lim JH, Park MS, Kim DY, Yoon JH, Kim WH, Kikuchi M, Tanaka J, Koyama Y, Kweon OK: Guided bone regeneration with betatricalcium phosphate and poly L-lactide-co-glycolide-co-epsiloncaprolactone membrane in partial defects of canine humerus. J Vet Sci 2006, 7:73-77,

129. Beniker D, McQuillan D, Livesey S, Urban RM, Turner TM, Blum B, Hughes K, Haggard WO: The use of acellular dermal matrix as a scaffold for periosteum replacement. Orthopedics 2003, 26(5 Suppl):S591-596.

130. Gerber A, Gogolewsky S: Reconstruction of large segmental defects in the sheep tibia using polylactide membranes. A clinical and radiographic report. Injury 2002, 33(Suppl 2):43-57.

131. Gugala Z, Gogolewski S: Healing of critical-size segmental bone defects in the sheep tibiae using bioresorbable polylactide membranes. Injury 2002, 33(Suppl 2):71-76. 
132. Gugala Z, Gogolewski S: Regeneration of segmental diaphyseal defects in sheep tibiae using resorbable polymeric membranes: a pilot study. $J$ Orthop Trauma 1999, 13:187-195

133. Kinoshita Y, Yokoya S, Mizutani N, Amagasa T, Kudo K, Nagayama M, Okabe S, Totsuka Y, Furuta I: Reconstruction of the mandible using bioresorbable poly[L-Lactide]mesh and autogenic particulate cancellous bone and marrow and application of dental implant. Head and Neck Cancer 2000, 26:525-530[http://sciencelinks.jp/j-east/article/200407/ 000020040704A0146649.php], [Abstract in English].

134. Ip WY, Gogolewski S: Clinical application of resorbable polymers in guided bone regeneration. European Cells and Materials 2004, 7(Suppl 1):36, [Abstract].

135. Berkovitz KBB: Disarticulated individual bones. In Gray's Anatomy: The Anatomical Basis of Clinical Practice.. 39 edition. Edited by: Standring S. London: Elsevier Churchill Livingstone; 2005:463-484.

136. Pedersen AB, Johnsen SP, Overgaard S, Søballe K, Sørensen HT, Lucht U: Total hip arthroplasty in Denmark: incidence of primary operations and revisions during 1996-2002 and estimated future demands. Acta Orthop 2005, 76:182-189.

137. Ulrich SD, Seyler TM, Bennett D, Delanois RE, Saleh KI, Thongtrangan I, Kuskowski M, Cheng EY, Sharkey PF, Parvizi J, Stiehl JB, Mont MA: Total hip arthroplasties: what are the reasons for revision? Int Orthop 2008, 32:597-604.

138. Mavrogenis AF, Coll-Mesa L, Gonzalez-Gaitan M, Ucelay-Gomez R, Fabri N, Ruggieri P, Papagelopoulos PJ: Criteria and outcome of limb salvage surgery. J BUON 2011, 16:617-626.

139. Sampo M, Koivikko M, Taskinen M, Kallio P, Kivioja A, Tarkkanen M, Böhling T: Incidence, epidemiology and treatment results of osteosarcoma in Finland - a nationwide population-based study. Acto Oncol 2011, 50:1206-1214.

140. Nicoli Aldini N, Fini M, Giavaresi G, Guzzardella GA, Giardino R: Prosthetic devices shaped as tubular chambers for the treatment of large diaphyseal defects by guided bone regeneration. Int J Artif Organs 2005, 28:51-57.

141. Jaroma HJ, Ritsilä VA: Behaviour of cancellous bone graft with and without periosteal isolation in striated muscle. An experimental study. Scand J Plast Reconstr Surg Hand Surg 1988, 22:47-51.

142. Greenstein G, Greenstein B, Cavallaro J, Tarnow D: The role of bone decortication in enhancing the results of guided bone regeneration: a literature review. J Periodontol 2009, 80:175-189.

143. Guerra I, Morais Branco F, Vasconcelos M, Afonso A, Figueiral H, Zita R: Evaluation of implant osseointegration with different regeneration techniques in the treatment of bone defects around implants: an experimental study in a rabbit model. Clin Oral Implants Res 2011, 22:314-322.

144. Yokoya S, Mochizuki Y, Nagata Y, Deie M, Ochi M: Tendon-bone insertion repair and regeneration using polyglycolic acid sheet in the rabbit rotator cuff injury model. Am J Sports Med 2008, 36:1298-1309.

145. Amado S, Simões MJ, Armada da Silva PA, Luís AL, Shirosaki Y, Lopes MA, Santos JD, Fregnan F, Gambarotta G, Raimondo S, Fornaro M, Veloso AP, Varejão AS, Maurício AC, Geuna S: Use of hybrid chitosan membranes and N1E-115 cells for promoting nerve regeneration in an axonotmesis rat model. Biomaterials 2008, 29:4409-4419.

146. Jung RE, Windisch SI, Eggenschwiler AM, Thoma DS, Weber FE, Hämmerle $\mathrm{CH}$ : A randomized-controlled clinical trial evaluating clinical and radiological outcomes after 3 and 5 years of dental implants placed in bone regenerated by means of GBR techniques with or without the addition of BMP-2. Clin Oral Implants Res 2009, 20:660-666.

147. Lee SJ, Park YJ, Park SN, Lee YM, Seol YJ, Ku Y, Chung CP: Molded porous poly (L-lactide) membranes for guided bone regeneration with enhanced effects by controlled growth factor release. J Biomed Mater Res 2001, 55:295-303.

148. Hong KS, Kim EC, Bang SH, Chung CH, Lee Yl, Hyun JK, Lee HH, Jang JH, Kim Tl, Kim HW: Bone regeneration by bioactive hybrid membrane containing FGF2 within rat calvarium. J Biomed Mater Res A 2010, 94:1187-1194.

149. Zellin G, Linde A: Importance of delivery systems for growth-stimulatory factors in combination with osteopromotive membranes. An experimental study using rhBMP-2 in rat mandibular defects. J Biomed Mater Res 1997, 35:181-190.
150. Kolambkar YM, Dupont KM, Boerckel JD, Huebsch N, Mooney DJ, Hutmacher DW, Guldberg RE: An alginate-based hybrid system for growth factor delivery in the functional repair of large bone defects. Biomaterials 2011, 32:65-74.

151. Kolambkar YM, Boerckel JD, Dupont KM, Bajin M, Huebsch N, Mooney DJ, Hutmacher DW, Guldberg RE: Spatiotemporal delivery of bone morphogenetic protein enhances functional repair of segmental bone defects. Bone 2011, 49:485-492.

152. Pinheiro AL, Limeira Júnior Fde A, Gerbi ME, Ramalho LM, Marzola C, Ponzi EA, Soares AO, De Carvalho LC, Lima HC, Gonçalves TO: Effect of 830-nm laser light on the repair of bone defects grafted with inorganic bovine bone and decalcified cortical osseus membrane. J Clin Laser Med Surg 2003, 21:301-306.

153. Dahlin C, Linde A, Röckert H: Stimulation of early bone formation by the combination of an osteopromotive membrane technique and hyperbaric oxygen. Scand J Plast Reconstr Surg Hand Surg 1993, 27:103-108.

154. Arisawa EA, Brandão AA, Almeida JD, da Rocha RF: Calcitonin in boneguided regeneration of mandibles in ovariectomized rats: densitometric, histologic and histomorphometric analysis. Int J Oral Maxillofac Surg 2008, 37:47-53.

155. Jung RE, Cochran DL, Domken O, Seibl R, Jones AA, Buser D, Hammerle CH: The effect of matrix bound parathyroid hormone on bone regeneration. Clin Oral Implants Res 2007, 18:319-325.

156. Weng D, Poehling S, Pippig S, Bell M, Richter EJ, Zuhr O, Hürzeler MB: The effects of recombinant human growth/differentiation factor-5 (rhGDF-5) on bone regeneration around titanium dental implants in barrier membrane-protected defects: a pilot study in the mandible of beagle dogs. Int J Oral Maxillofac Implants 2009, 24:31-37.

157. Donos N, Retzepi M, Wall I, Hamlet S, Ivanovski S: In vivo gene expression profile of guided bone regeneration associated with a microrough titanium surface. Clin Oral Implants Res 2011, 22:390-398.

158. Dupont KM, Boerckel JD, Stevens HY, Diab T, Kolambkar YM, Takahata M, Schwarz EM, Guldberg RE: Synthetic scaffold coating with adenoassociated virus encoding BMP2 to promote endogenous bone repair. Cell Tissue Res 2012, 347:575-588.

\section{Pre-publication history}

The pre-publication history for this paper can be accessed here: http://www.biomedcentral.com/1741-7015/10/81/prepub

doi:10.1186/1741-7015-10-81

Cite this article as: Dimitriou et al:: The role of barrier membranes for guided bone regeneration and restoration of large bone defects: current experimental and clinical evidence. BMC Medicine 2012 10:81.

\section{Submit your next manuscript to BioMed Central and take full advantage of:}

- Convenient online submission

- Thorough peer review

- No space constraints or color figure charges

- Immediate publication on acceptance

- Inclusion in PubMed, CAS, Scopus and Google Scholar

- Research which is freely available for redistribution

Submit your manuscript at www.biomedcentral.com/submit
Ciomed Central 